\title{
Fault core and damage zone fracture attributes vary along strike owing to interaction of fracture growth, quartz accumulation, and differing sandstone composition
}

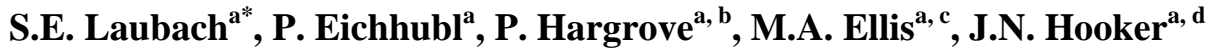

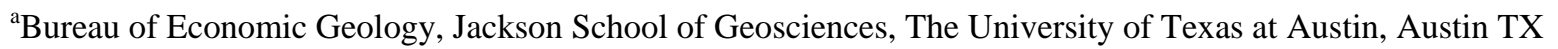 \\ 78713, USA \\ ${ }^{\mathrm{b}}$ BP America, Houston TX 77079, USA \\ ${ }^{c}$ Department of Geological Sciences, University of North Carolina, Chapel Hill, NC 27599-3315, USA \\ ${ }^{\mathrm{d} D e p a r t m e n t ~ o f ~ E a r t h ~ S c i e n c e s, ~ U n i v e r s i t y ~ o f ~ O x f o r d, ~ S o u t h ~ P a r k s ~ R o a d, ~ O X 1 ~ 3 A N, ~ U K ~}$ \\ *Corresponding author. Fax: +1 5124710140. \\ E-mail address: steve.laubach@beg.utexas.edu (S.E. Laubach)
}

\section{ABSTRACT}

Small, meter- to decimeter-displacement oblique-slip faults cut latest Precambrian lithic arkose to feldspathic litharenite and Cambrian quartz arenite sandstones in NW Scotland. Despite common slip and thermal histories during faulting, the two sandstone units have different fault-core and damage-zone attributes, including fracture length and aperture distributions, and location of quartz deposits. Fault cores are narrow (less than 1 meter), lowporosity cataclasite in lithic arkose/feldspathic litharenites. Damage zone-parallel opening-mode fractures are long (meters or more) with narrow ranges of lengths and apertures, are mostly isolated, have sparse quartz cement, and are open. In contrast, quartz arenites, despite abundant quartz cement, have fault cores that contain porous breccia and dense, striated slip zones. Damage-zone fractures have lengths ranging from meters to centimeters or less, but with distributions skewed to short fractures, and have power-law aperture distributions. Owing to extensive quartz cement, they tend to be sealed. These attributes reflect inhibited authigenic quartz accumulation on feldspar and lithic grains, which are unfavorable precipitation substrates, and favored accumulation on detrital quartz. In quartz breccia, macropores $>0.04 \mathrm{~mm}$ wide persist where surrounded by slow-growing euhedral quartz. Differences in quartz occurrence and 
size distributions are compatible with the hypothesis that cement deposits modify the probability of fracture reactivation. Existing fractures readily reactivate in focused growth where quartz accumulation is low and porosity high. Only some existing, partly cemented fractures reactivate and some deformation is manifest in new fracture formation in partitioned growth where quartz accumulation is high. Consequences include along-strike differences in permeability and locus of fluid flow between cores and damage zones and fault strength.

Keywords: Adhesive bond, Corridor, Damage zone, Diagenesis, Fault, Fracture, Joint, Quartz, Scaling, Spacing

\section{Introduction}

Faults are narrow zones of localized shear deformation typically composed of intensely deformed fault cores surrounded by a fault damage zone (Caine et al., 1996; Crider and Peacock, 2004; Shipton and Cowie, 2003; Shipton et al., 2006; De Joussineau and Aydin, 2007; Wibberley et al., 2008; Faulkner et al., 2010). Structural elements of brittle faults in low-porosity sedimentary rock include opening-mode fractures, also referred to as joints where barren, sheared opening-mode fractures, and smaller faults. Within fault cores, these elements coalesce to form cataclasite, gouge, and fault breccia. Differences between properties of deformed and undeformed rocks and the size, continuity, and porosity of structures in fault-core and damagezone influence whether faults are barriers or conduits for fluid flow (Bense et al., 2013). Fracture attributes provide information about fault growth (Chester and Logan, 1986; McGrath and Davison, 1995), fault strength (Caine et al., 1996; Evans et al., 1997; Shipton et al., 2002), and earthquake processes (Sibson, 1985). The structure of fault zones has been the subject of intense study over the past several decades (Kim et al., 2004; Mizoguchi et al., 2008; Childs et al., 2009; Mitchell and Faulkner, 2009; Faulkner et al., 2010; Long and Imber, 2010; Manzocchi et al., 
2010) and the role of cement accumulation in fault zones is increasingly recognized as modifying fluid flow conduits, strengthening faults, and providing evidence of fault history (Hippler, 1993; Fisher and Knipe, 1998, 2001; Foxford et al., 1998; Labaume and Moretti, 2001; Rawling et al., 2001; Fisher et al., 2003; Boles et al., 2004; Eichhubl et al., 2005, 2009; Woodcock et al., 2007; Laubach et al., 2010; Petrie et al., 2014).

Nevertheless, the extent to which cement precipitation and fracture growth interact to cause important differences in fault-zone properties over short distances is not fully appreciated. Fault studies have focused on faults in on poorly to moderately cemented sandstones or sandstoneshale sequences, reflecting their relevance in conventional oil and gas reservoirs. Faults in wellcemented sandstones, on the other hand—including those representative of unconventional oil and gas reservoirs - have received less attention. While many aspects translate from one reservoir type to the other, greater cumulative burial and thermal exposure for unconventional gas and oil sandstone reservoirs (in the range of 80 to $200^{\circ} \mathrm{C}$ ) favor cement precipitation, which may occur at rates comparable to fracture opening rates (Becker et al., 2010; Fall et al., 2012; Lander and Laubach, 2014). Fracture-cement precipitation, and the interaction between chemical and mechanical processes in fracture formation is thus likely to be more pronounced in controlling fault permeability compared to rocks and for conventional reservoirs at lower thermal exposure or maximum burial temperature.

Here, for fracture arrays associated with small-displacement, oblique-slip faults formed under sedimentary basin conditions (moderate temperatures to c. $100^{\circ} \mathrm{C}$ )(Figs. 1, 2), we show that, for the same faults, fault core and damage zone attributes vary markedly and abruptly from one wellcemented sandstone type to another (Table 1). Lithic arkose to feldspathic litharenite fault cores 
are matrix-rich cataclasite (indurated gouge) and probable flow barriers, whereas fault damage zones comprise long open fractures and are probable conduits. Quartz-arenite fault cores contain porous breccias that are conduits, whereas surrounding damage zones comprise mostly short, sealed fractures that are probable low fracture permeability zones or barriers. We account for these differences by inhibition of quartz accumulation on non-quartz substrates, particularly feldspar and lithic grains, and the large anisotropy in quartz growth among different accumulation-surface types, which tends to preserve fracture porosity under low-temperature conditions (Lander and Laubach, 2014). Differences in scaling of length and aperture size may arise if fractures have different propensities to reactivate and grow or to stagnate and seal, contingent on rock-type- and temperature-determined quartz-accumulation amounts (Hooker et al., 2012, 2013). At submetamorphic temperatures, small differences in rock type may lead to marked differences in structural style and permeability and to abrupt, but possibly predictable differences in fault strength.

\section{2. $\quad$ Setting}

In NW Scotland west of the ESE-dipping Paleozoic (Caledonian) Moine Thrust Zone (MTZ), red sandstones of the Proterozoic Torridonian succession are unconformable on the Archean Lewisian Gneiss Complex and are unconformably overlain by sandstones and carbonate rocks of the Cambro-Ordovician Ardvreck and Durness Groups (Johnstone and Mykura, 1989; Trewin and Rollin, 2002) (Fig. 1). The youngest part of the Torridonian, the early Neoproterozoic Torridon Group, was deposited c. $1000 \mathrm{Ma}$ (Kinnaird et al., 2007), and the four constituent units are up to $5 \mathrm{~km}$ thick (Stewart, 1996, 2002; Williams and Foden, 2011). In our study area, the Applecross Formation, the youngest unit of the Torridon Group, is dominantly reddish-brown, medium to coarse lithic arkose to feldspathic litharenite with pebble beds (Ellis et al., 2012). 
Beds are nearly flat lying. The overlying lowermost Cambrian unit, the Eriboll Formation, includes quartz arenite of the 75- to 125-m-thick Basal Quartzite Member and the younger 75- to 100-m-thick Pipe Rock Member (Park et al., 2002). Beds dip c. 12 degrees ESE.

Despite histories that probably involved deep $(>10 \mathrm{~km})$ and possibly protracted burial before and during emplacement of the Moine Thrust (Johnson et al., 1985; Hall and Bishop, 2002), Applecross and Eriboll Formation sandstones are indurated but unmetamorphosed sedimentary rocks. Owing to erosion of younger units, post-Caledonian exhumation is not closely constrained, but apatite fission-track data suggest multiple phases of cooling interpreted to record regional Triassic, Cretaceous, and Cenozoic exhumation (Holford et al., 2010), rather than monotonic cooling and denudation (Macdonald et al., 2007). Inferred Mesozoic temperatures of c. $80-90^{\circ} \mathrm{C}$ are compatible with sparse fluid inclusion homogenization temperature observations of c. $70-100^{\circ} \mathrm{C}$ from the youngest fracture sets in the Eriboll Formation (Laubach and DiazTushman, 2009).

Faults that cut both Applecross and Eriboll Formations and that postdate the Moine Thrust were recognized and mapped by Peach et al. (1907) and their contemporaries, and these faults have recently received more attention (Laubach and Marshak, 1987; Stewart, 1993; Knipe and Lloyd, 1994; Holdsworth et al., 1997, 2001; Roberts and Holdsworth, 1999; Beacom et al., 2001; Wilson et al., 2010; Elmore et al., 2010) (Fig. 1). Wilson et al. (2010) recognized a faulting sequence for northern Scotland that they attribute to regional events superposed on basement fabrics. Devonian rifting resulted in N-S to NNW-SSE striking faults. Permo-Triassic faults strike NE-SW and accommodated NW-SE extension. An ESE-striking strike-slip fault system is also present. Paleomagnetic studies of some red fault breccias ascribed to Mesozoic extension 
contain Triassic and Jurassic chemical remanent magnetization (Elmore et al., 2010) consistent with the inference that some faulting occurred in the Mesozoic era (Roberts and Holdsworth, 1999; Wilson et al., 2010). Jurassic sedimentation patterns in western Scotland could reflect episodes of footwall uplift on NE-striking faults (Roberts and Holdsworth, 1999; Hudson, 2011).

Several regional fracture sets are documented in both the Applecross Formation (Ellis et al., 2012; four sets) and Eriboll Formation (Laubach and Diaz-Tushman, 2009; five sets) on the basis of orientation, crosscutting relations, and cement content. Applecross sandstones tend to be sparsely fractured, and large areas of unfractured or sparsely fractured rock are present. Eriboll sandstone, on the other hand, is pervasively fractured. The youngest in both formations are associated with post-MTZ faults. Wide fractures in these sets are open but quartz-lined, whereas narrow fractures and microfractures are sealed. The timing of the two youngest Eriboll Formation fracture sets, with northerly and E-ENE strikes, are interpreted as Mesozoic or Tertiary in age (Laubach and Diaz-Tushman, 2009). On the basis of chemical remanent magnetization evidence, Elmore et al. (2010) suggest that the northerly striking set is Triassic and the E-ENE-striking set is Jurassic. Pleistocene glaciation accentuated some fault traces and probably caused some barren joint arrays (Goodenough et al., 2009; Krabbendam and Glasser, 2011). Our study encompassed the area shown in Figure 1. We focused on faults $\mathrm{Fa}$ and $\mathrm{Fb}$ and minor faults having $\mathrm{E}$ to ENE strikes.

\section{Methods}

We remapped selected contacts and parts of faults (at a scale of 1:10,000) in our study near An Teallach (Fig. 1). We obtained fault and fracture measurements using low-level (c. 10-melevation) kite photography for trace patterns and measurement along lines of observation 
(scanlines) at high angles to fault strike for fracture occurrence and aperture size. Host rock, fault, and fracture mineralogy and textures were documented using petrography and cathodoluminescence imaging obtained with a Phillips XL30 scanning electron microscope equipped with an Oxford Instruments MonoCL cathodoluminescence system. The SEM was operated at $12-15 \mathrm{kV}$ and at large sample currents for panchromatic CL imaging. Color CL images were obtained by combining three greyscale images produced using red, green, and blue filters. Macrofracture aperture sizes were measured in the field using a comparator containing lines having a graduated range of widths from 0.05 to $5 \mathrm{~mm}$ (Ortega et al., 2006) and microfractures were measured on SEM-CL images obtained from multiple contiguous thin sections (Gomez and Laubach, 2006; Hooker et al., 2011).

\section{Results}

\subsection{Rock properties and fault-zone attributes}

Applecross Formation sandstones in our study area are medium to coarse, immature lithic arkose to feldspathic litharenite having an average framework grain quartz:feldspar:lithic composition of $\mathrm{Q}_{60} \mathrm{~F}_{23} \mathrm{~L}_{17}$. Lithic fragments include argillaceous sedimentary rock fragments, phyllite and schist, and probable volcanic rock fragments, commonly in a penetratively deformed pseudomatrix between harder framework grains. Quartz overgrowths average 3 percent of the rock volume (0.3 to 8.2\%; n=19; Ellis et al., 2012). Cambrian Eriboll Formation sandstone, in contrast, is fine to medium, mature quartz arenite $\left(\mathrm{Q}_{95} \mathrm{~F}_{5} \mathrm{~L}_{0}\right)$. Intergranular volumes are medium to low and quartz cement is pervasive (16.5-21\%) (Laubach and Diaz-Tushman, 2009). Sandstones of both formations have very low to no porosity (0-1\%). Although both units are strongly indurated, Applecross lithic arkose to feldspathic litharenites have notably smallwe 
elastic stiffness (Young's modulus are 2.3 to $17 \mathrm{GPa}$; average $6 \mathrm{GPa}$ ) compared to the Eriboll quartz arenites (75 GPa) (Ellis et al., 2012).

Late, small-displacement faults (offset $<10 \mathrm{~m}$ ) cut across the Applecross-Eriboll Formation contact (Figs. 1, 2), striking NE-SW to EW; a few small N-S-striking faults are also present (Peach et al., 1907; Butler, 2009; this study). Aside from a cross-cutting relationship with the Moine Thrust Zone that shows that these faults are post-Caledonide, fault age is undetermined. Faults dip steeply (60-80 degrees). Fault cores are mostly poorly exposed but similar narrow core widths $(<\mathrm{m})$ are evident in both sandstone types. Cores comprise steeply dipping tabular zones of closely spaced fractures and narrow zones $(\mathrm{c} .10 \mathrm{~cm}-0.5 \mathrm{~m})$ of matrix- and clay-rich cataclasite (gouge) or breccia. Striations in both units include oblique slip indicators (Fig. 2) as well as some strike-slip and dip-slip striations, which in some cases are in adjacent parts of fault cores. Displacements from offset beds are compatible with left oblique-slip.

Faults are surrounded by discrete damage zones of mostly opening-mode fractures (joints and veins) that are more closely spaced than disseminated fractures of the same set in the same beds. The largest faults ( $\mathrm{F} a$ and $\mathrm{F} b$, Figs. 1, 2) erode along damage zones to narrow but pronounced topographic features that extend with straight traces for kilometers (Figs. 1, 2a-c). Some persistent linear topographic features comprise fractures spaced more closely than in surrounding rocks but they have no discernable offset (at 1:5000) or exposed slip surfaces. These persistent, narrow tabular fracture zones are fracture corridors (Questiaux et al., 2010). Long fault-trace lengths and small displacements have been found elsewhere in brittle rock (Walsh et al., 2002; Kim and Sanderson, 2005). 
Applecross and Eriboll Formation core and damage-zone attributes resemble those of other small-displacement faults in indurated sandstone. But in addition to the attributes common to both units, notable differences exist in fault cores and damage zones between the two formations (Table 1). Adjacent sandstones cut by the same faults allow comparison of fault cores and damage zones in different sandstone types for the same faults (for example, Fig. 1, Fa, Fb). Owing to small offset, these attributes reflect deformation within each sandstone type rather than juxtaposition of differing sandstones.

\subsection{Fault cores}

\subsubsection{Applecross Formation fault cores}

In the two sandstone units, fault cores differ in structural fabric, the volume of quartz cement, and porosity. In Applecross lithic arkose/feldspathic litharenites, fault cores consist of two parts: tabular zones, usually less than $1 \mathrm{~m}$ wide, of opening-mode fractures that are markedly more closely spaced than those in surrounding damage zones, and narrow zones of indurated matrixand clay-rich cataclasite or gouge in the center of the damage zone (Figs. 3-5). Overall, faultcore rocks are strongly indurated and cohesive.

Cataclasite is present in narrow tabular domains, from 10 to $50 \mathrm{~cm}$ wide, traceable for at least a few to tens of meters (Fig. 3). Within these cataclasite zones are tabular to lenticular zones that locally are as little as 50 microns wide of differing texture and grain sizes. Some boundaries are gradual, whereas others are abrupt. In thin section, cataclasite is dominantly small brittly deformed clasts, clast fragments and pseudomatrix (deformed lithic grains) with incipient foliation from shape-preferred orientations of broken clasts, deformed ductile lithic grains, and probable new clay mineral growth. Textures record brittle grain-fragmentation, rotation of grains 
and grain particles, and particle displacement. Slip surfaces are marked by striations from breakage, attenuation, and alteration of lithic and feldspar grains.

Quartz cement is present in microfractures within quartz grain fragments or radiating from grain contacts. This pattern shows that quartz precipitated during fault-rock formation, but these traces of cement show that quartz is only marginally more abundant in core rocks than in adjacent sandstones. On the micro-scale, open fractures are mostly sample-preparation artifacts. Evidence of dilatancy is rare and no quartz-filled macrofractures are evident. Grain-size reduction accompanied by ductile deformation of lithic clasts resulted in fine-grained, lowporosity fault rock (Figs. 4, 5).

\subsubsection{Eriboll Formation fault cores}

In quartz arenites, fault cores include areas of closely spaced opening-mode fractures and zones of dense, quartz-cemented striated-fault rock and tabular to lenticular quartz-cemented breccia with local large, quartz-crystal-lined cavities (vug porosity) (Figs. 6-8). Breccia comprises grains and quartz cement broken into angular and tabular clasts having a wide size range, from a few microns to centimeters, where the latter clasts contain several detrital grains and surrounding cement (Fig. 8). Breccia fabrics are either compact with low interclast volume or dilatant with moderate to high interclast volume. These textures resemble other deformed lowporosity quartz arenites (Cook et al., 2006).

Breccia within the quartz arenite contains a wide size range of quartz-filled and quartz-lined microfractures in all fabric zones. Crosscutting quartz-filled microfractures show that some cement was subsequently broken and partly resealed later by quartz cementation during progressive fault movement (Fig. 8). Crosscutting fractures and growth textures are compatible 
with crack-seal mechanisms accompanying grain-size reduction and slip. Zoned authigenic quartz cement has low luminescence (Fig. 8) and is in optical continuity with quartz clasts. The width of completely quartz-filled microfractures ranges from $0.0015 \mathrm{~mm}$ to $0.007 \mathrm{~mm}$, although locally partly open fractures have width-spanning quartz deposits that are thicker. These thick deposits have crack-seal texture as a result of repeated fracturing and cement accumulation on the additional fracture-surface area. Quartz deposit thicknesses on open vug walls ranges from 0.004 to $0.018 \mathrm{~mm}$ (median $0.007 \mathrm{~mm}$ ). Some variability arises from the prismatic shapes of quartz crystals, but thickness also varies along vug walls depending on wall orientation, probably reflecting accumulation differences depending on substrate crystallographic orientation.

Quartz cement is pervasive within breccia but the amount of porosity is variable. Cemented dilatant-fault breccia contains zones lacking or having only trace porosity and breccia bodies containing large ( $\mathrm{mm}$ to $>\mathrm{cm}$ ) vug porosity. Low-porosity breccia typically has small betweenclast areas (less than $0.04 \mathrm{~mm}$ ) (Fig. 8b) filled with quartz or smaller particles. Where betweenclast areas are about $0.04 \mathrm{~mm}$ or larger, dilatant breccia is locally notably porous (Fig. 6), having as much as 15 percent porosity in wide quartz-lined fractures and vugs (breccia and cementbounded cavities). In these intervals, open vugs commonly are interconnected. Extensive red iron stain occurs along breccia zones amidst typically white-weathering, dense, non-porous Eriboll sandstones (Fig. 7) and modern groundwater flow at this site and elsewhere shows that these porous zones are commonly permeable.

Brecciated cores are narrow (centimeters to c. $1 \mathrm{~m}$ ) and have broadly tabular, tapering, and irregular shapes. Tapering to irregular breccia bodies and en echelon offsets of a few wellexposed cm- and meter-scale examples (Figs. 7, 9, 10) suggest breccia is discontinuous and 
possibly arranged in left- and right-stepping patterns. For the widest brecciated cores, the tapering shapes of zones suggest moderate along-strike discontinuity (1 to $5 \mathrm{~m}$ ). Breccia is not necessarily developed symmetrically in the center of damage zones. Some breccia is situated near damage-zone boundaries, and changes in relative position along strike within damage zones.

\subsection{Fault damage zones}

In the two sandstone units, damage zones are marked by greater fracture abundance as compared to the abundance of background fractures (Fig. 11) and by recessed topography. In both types of sandstone, damage zones are dominated by opening-mode fractures that strike between parallel to oblique ( 0 to 40 degrees) to fault traces. Outer margins of damage zones are defined by abrupt increases in fracture abundance toward faults with greater fracture intensity (more fractures/meter; closer spacing) compared to background fractures (Fig. 11). Inner margins of damage zones are marked by the occurrence of cataclasite or breccia. For Applecross sandstones, intensity within damage zones is typically more than 5 fractures/meter, compared to background intensity of 1 fracture/m or less (Figs. 11, 12). Intensity in Eriboll sandstone damage zones is higher, commonly greater than 15 fractures/meter. But in Eriboll sandstones, background fracture abundance is also greater (Figs. 9, 10) than in Applecross sandstones. Fracture abundance (and, locally, length) diminishes near Applecross Formation damage-zone boundaries. Boundaries are diffuse and would be challenging to recognize in rocks having greater overall background fracture abundance. Eriboll Formation damage-zone margins are typically abrupt and commonly marked by long fractures (Fig. 2). We found no correlation between background intensity and relative distance from the zone boundary, and in figure 11 we arbitrarily sorted Eriboll Formation background fracture data sets by intensity. 
Damage zones include subsidiary fractures diverging from near fault-parallel fracture tips at angles of 30 to 40 degrees, in wing-crack configurations (Willemse and Pollard, 1998), structures that result from slip on preexisting fractures. Although common in both formations, wing cracks are more prevalent in Eriboll Formation damage zones than in the Applecross Formation, possibly because preexisting fractures are more common. Wing cracks on slipped opening-mode fractures aligned subparallel to fault traces are compatible with left oblique-slip, but, within damage zones, wing cracks also form on preexisting fractures in other orientations, leading to complex patterns. Damage-zone complexity is high in Eriboll sandstones, owing to the prevalence of this hierarchy of wing crack patterns. Complex wing crack arrays have also been described for other faults where preexisting fractures are present (van der Zee et al., 2008).

Qualitatively, fractures in Applecross sandstone damage zones are mostly isolated, in part because fractures are widely spaced and subparallel, and wing cracks are less common than in Eriboll Formation damage zones (Fig. 12b; Ellis et al., 2012, their figure 15). In Eriboll sandstone damage zones, the combination of prevalence of wing cracks, wider strike range, more-closely spaced fractures, and more-numerous preexisting fractures cut by fault zones means that these fractures are mostly physically interconnected whereas those in Applecross sandstone are not.

Faults have straight traces that are up to several kilometers long. For Applecross sandstones, damage-zone lengths are exposed all along the faults, but recessed weathering means that alongstrike variability in width and internal structure is uncertain. Damage zones are meters to tens of meters wide. Four of the largest Applecross Formation damage zones have an average width of $24 \mathrm{~m}$ (range 11 to $37 \mathrm{~m}$ ). 
Although for the largest faults, Eriboll Formation fault cores are not well exposed, wellexposed $\mathrm{cm}$ - and $\mathrm{m}$-scale damage zones in Eriboll sandstones suggest that damage-zone patterns in this unit are in left- and right-stepping relay patterns over a range of scales. Nevertheless, for larger faults, we infer, partly on the basis of topography, that damage zones are fairly uniform in width along fault traces and have similar widths in the two adjacent sandstones (Fig. 2). Long fault traces, wide damage zones, and small offsets are consistent with length and damage-zone width established early during fault propagation (Ferrill et al., 2008).

Microfractures are common as a component of disseminated fracture sets in Eriboll sandstones (Fig. 13) but rare in association with late Applecross Formation fracture sets. Microfracture orientation patterns and cross-cutting relations match those of larger fractures. Although microfracture abundances that increase toward faults are known (Anders et al., 2014), in our example, microfracture abundance varies abruptly along the fault trace but not acrossstrike for the fault. Microfracture abundance in the Applecross Formation is small and no pattern of increased abundance toward the fault is evident, except perhaps for variations within parts of the fault core. In Eriboll sandstone, microfractures are widespread outside of and within damage zones (ranging from ca. 0.02 to 1 fractures/m for microfractures having opening displacements of about $0.05 \mathrm{~mm}$ ). They are abundant within damage zones and more abundant in fault cores, but a gradient in microfracture intensity is absent.

Fracture-height patterns are similar between the two sandstone units. A range of openingmode fracture heights is evident in both Applecross and Eriboll sandstones. Although other parts of the Applecross Formation contain sandstones having variable mechanical layering bounded by distinct, closely spaced bedding interfaces, in this area both Applecross and Eriboll sandstones 
have meters-thick fractured beds with few well-defined mechanical interfaces spaced centimeters to meters apart (in both cases mostly interfaces or zones of finer grain size). Height patterns for the tallest macroscopic fractures are comparable, on the order of meters, and these fractures are unbounded. Shorter fractures are confined within beds (top bounded/hierarchical) (height classification: Hooker et al., 2013). This distinction suggests that, although the average depositional bed thickness, mechanical properties and the average spacing of macroscopic fractures differ between the two units, fractured-layer thicknesses (Laubach et al., 2009) are similar enough to allow valid comparison of map-view trace-length and kinematic-aperture patterns.

Trace-length patterns on bed surfaces differ between the two units (Fig. 14). Damage-zoneparallel opening-mode fractures in Applecross sandstone are 1-5 m long (median, $1.7 \mathrm{~m}$ ), and few shorter fractures are present. Fractures that are $5 \mathrm{~m}$ or more in length are common, and probably have tracelengths truncated by censoring at outcrop boundaries. Therefore the outcrop inventory likely underestimates the prevalence of long fractures (Mauldon et al., 2001). The largest trace-length data set is well described by an exponential length distribution (Fig. 12). Eriboll lengths range from microfractures (c. 100 microns long) to rare fractures meters or more long (Fig. 2). Eriboll Formation fracture trace-length distributions are less certain owing to the prevalence of intersecting short fractures, but the range of lengths is greater than those of the Applecross sandstone, with many more short (cm-m scale) fractures. Greater abundance of short fractures is more apparent if the abundant microfractures in Eriboll sandstones are considered. Erosion of the widest damage zones precludes complete length inventories for the longest fractures, although there are at least some fractures $\sim 5 \mathrm{~m}$ long. But the Eriboll Formation pattern 
of trace lengths skewed toward small sizes is apparent in several well-exposed narrow damage zones (Fig. 14).

The exponential distribution of mostly long fractures of the Applecross Formation contrasts with the wider range of lengths, skewed toward short traces, of the Eriboll Formation, but incomplete exposures of the longest fractures and ambiguity in defining lengths impede rigorous length comparison. Measuring lengths can be subjective because isolated fractures cannot always be rigorously distinguihsed from en echelon arrays (Ortega and Marrett, 2000). Fracture linkage poses a challenge for the grouping or splitting of linked fractures. The length and aperture distributions of isolated or en echelon fractures are expected to differ (Vermilye and Scholz, 1995; Olson, 2003), but our results leave unresolved the challenge of obtaining length data to compare to length-aperture scaling models. Inspection of fractures visible at a range of scales shows that some apparent single traces are en echelon arrays (Fig. 12b) or are formerly separate en echelon segments that have linked (Fig. 13b). At a specific map scale, we measured length if fractures appeared to define a single trace. We used the same trace-length measurement convention for both formations for distinguishing single traces from en echelon arrays.

One-dimensional measurements of kinematic apertures or total opening displacement along scanlines are a less ambiguous measure of size than are length measurements. We quantify kinematic aperture size distributions by plotting cumulative frequency of the fracture-size rank divided by scanline length (Marrett, 1996; Marrett et al., 1999). This technique allows data from different scales of observation to be compared in the same graph, and controls for scanlines of different length collected at a single observation scale. Aperture patterns differ between the two units (Fig. 15). Applecross sandstone contains very few microfractures (in many cases none are 
evident for the late fracture sets), so the range of aperture sizes is smaller than that of the Eriboll Formation, which contains numerous microfractures. Apertures of macroscopic fractures in the Applecross Formation are narrow and challenging to measure accurately in the field. A small but representative data set shows a restricted aperture size range (0.095 to $4 \mathrm{~mm})$ with an average of about $1 \mathrm{~mm}$ (Fig. 15). The measured size range may be exaggerated by the effects of weathering that creates an apparent aperture greater than the fracturing-created aperture (thus the actual size range may be narrower than these measurements suggest). The measured pattern is compatible with a lognormal distribution. Apertures of macroscopic fractures in Eriboll sandstone have a wider range, and these fractures are associated with numerous microfractures also having a wide range of kinematic apertures (Figs. 9, 10). For Eriboll microfractures and macrofractures collected from the same rock body and plotted together by normalizing to scanline length, consistent cumulative frequency patterns are evident over more than three orders magnitude (Fig. 15). These size patterns are well described by power laws (Hooker et al., 2011).

The porosity, volume and textures of quartz cement in fractures vary between the two units. Applecross Formation fractures have sparse quartz cement (Fig. 13). Quartz is typically present as small faceted crystals (height c. $0.015 \mathrm{~mm}$ or less) localized on quartz grains and facing openfracture pore space. Quartz deposits are commonly surrounded by nonmineralized fracture wall where clay-rich pseudomatrix, lithic grains, or feldspar is present. Quartz deposits that span between fracture walls are rare for late fault-associated fractures, but are more common in older sets, and are confined to the narrowest fractures or fracture tips where large quartz grains are bisected by fractures. Crystals are localized on quartz grains and pre-existing cement cut by fractures, but not on adjacent feldspar or lithic grains or pseudomatrix. Porosity is apparent in most fractures. The open fractures frequently weather to negative relief, which impairs aperture 
measurements, and some fracture surfaces are probably altered by modern groundwater flow. Red-stained sandstones commonly weather white in narrow halos around fracture traces (Fig. $12 b$ ), suggesting the fractures are conduits for groundwater flow.

Quartz cement is widespread in Eriboll Formation fractures, lining or filling fractures (Fig. 13). The narrowest microfractures are filled with massive, textureless quartz. Fractures narrower than $0.03 \mathrm{~mm}$ are generally entirely sealed and most fractures $0.07 \mathrm{~mm}$ wide are sealed (Fig. 15). Consequently numerous small fractures and narrow fracture tips are sealed. Wider fractures locally are spanned by quartz that contains crack-seal texture (Fig. 13). These textures demonstrate repeated fracture opening during cement precipitation (Fig. 13). In fault cores, some of the thickest veins are partly filled with cataclasite. These veins also vary in thickness along strike to a greater extent, and more abruptly, than do background opening-mode fractures. Cement deposits that span partly open fractures are as much as $0.13 \mathrm{~mm}$ thick. Such fractures may have open pore space between deposits that are as much as $0.05 \mathrm{~mm}$ wide. The widest fractures $(0.1 \mathrm{~mm}$ or more) are lined by quartz that has crystal shapes that indicate that they grew into open-fracture pore space. These quartz cement amounts and textures are similar to those in fault-core vugs. Quartz deposit thicknesses resemble those in Applecross fractures, but in Eriboll fractures the deposits are present over the entire fracture wall.

\section{Discussion}

Fault style can vary with sandstone rock type (Johansen and Fossen, 2008). In our example, contrasts are present between lithic and feldspar-rich and quartz-rich sandstones along faults that share a common slip and thermal history (Table 1). Differences correlate with mechanical properties and expected effects of sandstone composition — the type of grain substrate—on 
cement precipitation. The small elastic stiffness of Applecross sandstones compared to stiff and brittle Eriboll Formation sandstones accounts for low fracture abundance in lithic and feldsparrich sandstone compared to adjacent quartz arenites (Ellis et al., 2012). But these mechanical properties do not account for differences in cement amounts, textures, porosity, and permeability of fault cores and damage zones, or differences in fracture-size distribution patterns.

Sandstones that were exposed to temperatures in excess of $90^{\circ} \mathrm{C}$ for millions of years generally contain significant volumes of quartz cement (McBride, 1989; Bjørklykke and Egeberg, 1993; Lander and Walderhaug, 1999) as overgrowths on pre-existing quartz surfaces such as detrital grains and earlier-formed cements. In settings where precipitation is not limited by the sources or transport modes of the cement solutes, the rate-limiting control on quartz overgrowth accumulation is the precipitation rate, governed by temperature and accumulation area (Walderhaug, 1996, 2000; Walderhaug et al., 2000; Lander et al., 2008). Quartz grains and cement provide accumulation area, but clay mineral and other cement coats on quartz grains and non-quartz grains inhibit quartz cementation (Heald and Larese, 1974; Ajdukiewicz and Larese, 2012).

These insights explain why temperature history is an important control on quartz cementation in fault zones (Hesthammer et al., 2002; Fisher et al., 2003), and also suggest why sandstones with differing composition and hence differing accumulation surface-area subject to the same thermal history during faulting might experience different amounts of quartz accumulation. The lithic arkose to feldspathic litharenites that we examined have unfavorable feldspar and lithic grain precipitation substrates and experienced inhibited quartz accumulation in fault-core and damage-zone fractures, in contrast to the quartz arenites where quartz cement is widespread in 
both parts of the fault zone. Thus in lithic and feldspar-rich sandstone, grain-size reduction and penetrative deformation of lithic grains result in matrix-rich cataclasite (gouge) with little or no intergranular volume for cement accumulation and no porosity. In contrast, quartz-rich sandstone has quartz-cemented breccia. But substrate effects do not explain residual macroporosity of quartz-lined macropores (vugs) in quartz arenite breccia and the resulting zones of high porosity and permeability.

Quartz-lined macropores (vugs) in quartz arenite breccia are examples of persistent macroporosity that is widespread in fractured, quartz-cemented sandstones. Fluid-inclusion and burial-history analysis shows that open, quartz-lined fractures (which are vug-like pores) can persist at temperatures above $130^{\circ} \mathrm{C}$ for millions of years (Becker et al., 2010; Fall et al., 2012). Locally, such fractures contain isolated quartz-bridge deposits exhibiting crack-seal textures (Laubach et al., 2004) that differ in configuration of zoned quartz and crack-seal texture and the presence of copious porosity from textures within thoroughly cement-filled quartz veins formed at higher temperatures (Fisher and Brantley, 1992; Hilgers et al., 2001).

An analysis of how these cement bridges and associated porosity form despite protracted accumulation of quartz cement (Lander and Laubach, 2014) also explains the persistence of open vugs in quartz-rich fault rock. Cement textures in fractures are marked by a tendency for quartz to preferentially grow on fractured quartz substrates but not on feldspar and lithic grains, and by markedly slower rates of quartz accumulation on faceted quartz in large cavities (Lander and Laubach, 2014). Laboratory quartz-growth experiments and crystal-growth simulations show that slow-growing crystal faces become more prevalent as crystal growth proceeds (Lander et al., 2008; Lander and Laubach, 2014). This result is in accord with quartz-cement-accumulation 
observations and models that show, other factors being constant, that average rate of quartz precipitation per surface area declines by nearly an order of magnitude during the course of cement growth, reflecting the progressive increase in the proportion of accumulation surface area that is made up of slow-growing euhedral faces as porosity declines (Lander et al., 2008).

Damage-zone fractures that are narrow readily sealed, but wider fractures that lack bridges have low quartz-cement volumes. In fault cores, progressive grain breakage renews fracture surface area, and overall quartz volume is greater than in damage zones. Fracture porosity persists because vugs become surrounded by slow-growing crystal surfaces.

\subsection{Implications for fault fluid flow properties}

Many fault zones are channels for hydrothermal fluids (Sibson et al., 1975; Bruhn et al., 1994; Boles et al., 2004) and our assumption that the sources or transport modes of cement solutes do not dominate quartz accumulation may be violated for other fault zones. In our faults, cement volumes and textures are compatible with quartz accumulation limited by thermal exposure and type of accumulation surface area rather than by advection. The crack-seal bridges in Eriboll Formation fractures, for example, are hard to explain by accumulation dominated by silica supply. Advection is not precluded, but we infer that transport of solutes is not the dominant effect on quartz accumulation in this case. If this inference is correct, quartz volumes and crystallographic information along with thermal-history information could be used to assess fault timing, since quartz-deposit thicknesses should reflect thermal history of the fracture surfaces (Lander and Laubach, 2014, their figure 3). But the uncertain burial history of NW Scotland impedes testing this idea. Low quartz-cement amounts are broadly consistent with published 
interpretations that these faults are Mesozoic or Tertiary and formed at temperatures of c. 70 to $100^{\circ} \mathrm{C}$ during cooling.

Owing to differences in the sandstone composition, our results show that open and sealed fractures that are potential conduits and flow barriers can exist simultaneously in fault zones in different rock types as the result of the same simple structural history. In the modern groundwater regime, qualitative observations of fluid flow and staining shows these structures are either conduits or flow barriers depending on rock type, suggesting they could play the same role in the subsurface.

Our results add complexity to accounts of fault-zone attribute patterns. According to some models, if fault cores consist of fine-grained fault products with mineral deposits or alteration (as in our example), and damage zones are dominated by opening-mode fractures (as in our example), fluid flow should be localized in the damage zone rather than in the less permeable fault core (Caine et al., 1996). Yet our example shows that, owing to cement precipitation patterns that differ by rock type, opening-mode fractures in damage zones may be less effective flow conduits than those in fault cores and vice versa. Depending on which sandstone hosts the structures, the location of likely flow conduits switches along strike and vertically from core to damage zone. These differences correlate with differences in fracture size that could further affect how fractures influence fluid flow.

Determinants of fracture-enhanced fluid flow are fracture length, length distribution, connectivity, and aperture. These size attributes vary along the fault zone. If fractures are open, more interconnected (Long and Witherspoon, 1985) and longer (Philip et al., 2005), fractures increase permeability. Fracture cement, however, may modify effective (open) length as well as 
decrease or eliminate open apertures. Eriboll Formation damage-zone fractures include narrow fractures (and many narrow fracture tips) (less than $0.1 \mathrm{~mm}$ wide), and have quartz-rich composition prone to accumulate quartz, and therefore they are more prone to be sealed. Narrow interconnecting fractures and sealing of narrow fracture tips can cause marked reduction of effective lengths and effective connectivity for flow (Olson et al., 2009). Although, on the basis of geometry alone, the physically more interconnected, more numerous and locally equally long fractures of the Eriboll Formation look like excellent flow conduits, they are probably less effective than those in Applecross Formation sandstones. These sandstone have walls that are not prone to quartz accumulation, are generally wider than the spanning potential of quartz (as defined by Lander and Laubach, 2014) for their temperature history, and above a certain fracture width tend to be open with negligible quartz cement (Fig. 15), implying that these long fractures are effective fluid conduits. Thus the same quartz precipitation processes that explain contrasts in fault-core attributes can account for the opposite porosity and permeability patterns in damagezone fractures. This example shows governance of potential fluid flow variations by the spatial heterogeneity of small-scale structures along and across faults (Lunn et al., 2008).

Fracture size and fracture diagenesis may not be independent variables. Size-distribution patterns in damage zones are notably different between the two sandstones. These differences might arise from the markedly different mechanical properties of these two units. But the interaction of cement precipitation and fracture growth may also explain the pattern. The cement adhesion mechanism proposed by Hooker et al. $(2012,2014)$ hypothesizes that contrasts between narrow fracture-size ranges (size-restricted or characteristic size distributions, such as those in the Applecross Formation) and power-law size distributions, such as those in the Eriboll Formation, could result from differing propensities of existing fractures to grow or for new 
fractures to form, contingent on cement accumulation rates. If the cement-bond strength and cement volume (or surface area) in fractures is sufficient, fracture-spanning cement may cause some fractures to resist reopening (possibly through adhesion of fracture walls). Where quartz accumulation is low (little fracture spanning cement) and porosity high, fracture lengths tend to be large but fractures have a narrow size range, because existing fractures readily reactivate in focused growth. The strength ratio of host rock and fracture causes new fractures to partition into the cemented fracture or the host rock (Caputo, 2010; Holland and Urai, 2010; Virgo et al., 2013).

Fractures tend to have a wide size range where quartz accumulation is high (crack-seal texture and sealed microfractures), and only some existing partly cemented fractures reactivate and some new fracture formation occurs in partitioned growth. This model predicts, for low-quartzaccumulation Applecross Formation fractures, a narrow distribution of large fractures and little evidence, such as high cement volumes or crack-seal texture, that quartz accumulation interfered with fracture growth. This pattern is opposite to the quartz-rich Eriboll Formation fractures. The model predictions are consistent with our observations.

\subsection{Implications for fault strength}

Fault behavior can be influenced by the mechanical properties of fault rock and surrounding rock, for example, the markedly different stiffness possessed by Applecross and Eriboll sandstones. But the contrasts in Applecross and Eriboll Formation fault-core rock types suggest that the strength of the fault core and damage zone varies along strike and dip. Moreover, the differing susceptibilities of fault-core rocks to quartz precipitation imply that each part of the fault core may differ in how strength changes with time as damage accumulates. Development of 
locally clay-rich foliated cataclasite in Applecross Formation fault cores suggests a weakening fault. Impeded quartz accumulation means no counteracting cementation process exists to heal damage accumulation, or strengthen the fault as damage accumulates.

Copious quartz deposition in Eriboll Formation fault cores and damage zones likely has a countervailing, strengthening effect. Here, brittle deformation and fault weakening by grain-size reduction is paired with strength recovery by quartz cementation. The recovery process and cement bonding are most complete in narrow fractures. But cementation is incomplete in localized zones of macropores owing to slow quartz accumulation in large cavities. Strength recovery may be impeded. This cement-accumulation pattern results in local zones of highly porosity and, therefore, potentially weak fault rock. Although quartz accumulation will gradually strengthen these zones by filling the vugs, empirical evidence (Becker et al., 2010) and models (Lander and Laubach, 2014) show that, at low temperatures (less than $100^{\circ} \mathrm{C}$ ), the time scale for filling large voids can be much longer-millions of years—-than for compact breccia with small pores. Many parts of the fault core, having narrow fractures or compact breccia, can seal in hours to hundreds of years at $100^{\circ} \mathrm{C}$ (Brantley et al., 1990; Lander and Laubach, 2014), but the overall rate of quartz accumulation in dilatant, vuggy breccia is likely to be far slower as initial rapid quartz accumulation gives way to accumulation on faceted crystals lining the vugs, a process that is 20 to 30 times slower. Quartz accumulation rates from Lander and Laubach (2014), low temperatures recorded by syn-faulting fluid-inclusion assemblages, and the history of postCaledonide exhumation and cooling of NW Scotland (Holford et al., 2010) are compatible with porosity preservation in fault-related vugs. 
The persistence of open-fracture pore space for millions of years at temperatures well above those experienced by the late faults in NW Scotland suggests that, although parts of quartz-rich fault cores may strengthen rapidly, other parts may remain persistently porous and probably weak. Because cementation effects are sensitive to temperature history, differences in inferred fault properties can evolve with time. What constitutes large pores and how long they will take to fill depends on temperature and rock composition in predictable ways (Lander and Laubach, 2014). Our example shows that weakening and strengthening effects can vary in opposite directions along the same fault trace, depending on the composition of the host rock.

Our example shows that different cementation and structural mechanisms can operate under the same conditions in different rock types. Heterogeneous cementation and porosity preservation could be mechanisms that create time-dependent heterogeneous physical properties that could, for example, account for aftershocks along the sides of rupture zones (Hu et al., 2013). Cement accumulation is recognized to cause re-seal hardening and cause permeability to be transient in dilatant fault zones (Woodcock et al., 2007; Fisher and Brantley, 2014).

Diagenetic models (Lander and Walderhaug, 1999; Taylor et al., 2010; Lander and Laubach, 2014) applied to fault zones could help predict how key porosity and strength attributes vary. For example, such models could identify where and at what rate differences in quartz-cement strengthening are likely to occur. Along-fault rock-composition information (and thermal-history data) is a key ingredient for such predictions.

\section{Conclusions}

This study provides a testable model that can be used to predict key fluid flow characteristics and strength of fault zones. The examples presented are useful because the configuration of 
faults cutting sandstones of different composition provides controls on variables that affect the evolution of fractures, notably cementation owing to rock-type differences.

Under moderate temperatures (up c. $100^{\circ} \mathrm{C}$ ) for the same oblique-slip faults in NW Scotland, interaction of fracture growth and quartz precipitation causes along-strike differences in potential locus of fluid flow, from fault core to damage zone, and the distribution of strong fault rock. In Applecross Formation fault cores, grain fracture and attenuation of lithic and feldspar grains lead to low-porosity clay- and matrix-rich cataclasite (indurated gouge), but, on opening-mode fracture walls in damage zones, the small number of quartz substrates inhibits quartz accumulation and preserves fracture porosity. In Eriboll Formation fault cores, ample quartz accumulation surfaces localize cement, forming dense quartz-cemented breccia, but cavities larger than about $0.04 \mathrm{~mm}$ preserve porosity because quartz accumulates at slower rates after crystals become faceted.

Open fractures may grow or reactivate preferentially, accounting for narrow distributions of trace lengths and aperture size in Applecross Formation damage zones. Progressive deformation is focused into existing fractures. In contrast, the presence of ubiquitous favorable quartz accumulation sites on fracture walls causes pervasive fill in narrow Eriboll Formation fractures. The tendency for narrow fractures to seal may explain large trace length distributions and powerlaw aperture size distributions for Eriboll Formation damage-zone fractures. With progressive deformation, some fractures reactivate but others do not. Progressive deformation is partitioned between existing and new fractures.

Fault cores switch from probable barriers to conduits, and damage zones from conduits to barriers, along same fault zones. Differences in rock type, here a shift of a few percent of whole- 
rock volume of lithic and feldspar grains versus quartz, lead to a marked difference in the size, shape, and porosity of fractures. These attributes and evidence for groundwater flow in the open fractures (Eriboll fault cores; Applecross damage zones) suggest that these differences also correspond to marked contrasts in permeability. In fault cores, abrupt along-strike differences from clay- and matrix-rich cataclasite to porous quartz breccia correspond to probable differences of fault strength that diagenetic models may be able to predict.

\section{Acknowledgments}

This study was funded by grant DE-FG02-03ER15430 from Chemical Sciences, Geosciences and Biosciences Division, Office of Basic Energy Sciences, Office of Science, U.S. Department of Energy. Our work on fractures is partly supported by the Fracture Research and Application Consortium at The University of Texas at Austin. Field work was supported by the GDL Foundation and the Jackson School of Geosciences. We are grateful to M. Krabbendam for images created using NEXTMap Britain elevation data and to Juliet Crider, Charlie Onasch and Bill Dunne for insightful review comments.

\section{References}

Ajdukiewicz, J.M., Larese, R.E., 2012. How clay grain coats inhibit quartz cement and preserve porosity in deeply buried sandstones: an experimental investigation. AAPG Bulletin 96(11), 2091-2119.

Anders, M.H., Laubach, S.E., Scholz, C.H., 2014. Microfractures: A review. Journal of Structural Geology. doi: 10.1016/j.jsg.2014.05.011

Beacom, L.E., Holdsworth, R.E., McCaffrey, K.J.W., Anderson, T.B., 2001. A quantitative study of the influence of pre-existing compositional and fabric heterogeneities upon fracture-zone development during basement reactivation. Geological Society, London, Special Publication 186, 195-211.

Becker, S.P., Eichhubl, P., Laubach, S.E., Reed, R.M., Lander, R.H., Bodnar, R.J., 2010. A 48 m.y. history of fracture opening, temperature, and fluid pressure: Cretaceous Travis Peak Formation, East Texas basin. Geological Society of America Bulletin 122(7/8), 1081-1093. doi: 10.1130/B30067.1. 
Bense, V.F., Gleeson, T., Loveless, S.E., Bour, O., Scibek, J., 2013. Fault zone hydrogeology. EarthScience Reviews 127, 171-192. doi: 10.1016/j.earscirev.2013.09.008.

Bjørklykke, K., Egeberg, P.K., 1993. Quartz cementation in sedimentary basins. AAPG Bulletin 77, $1538-1548$.

Boles, J.R., P. Eichhubl, P., Garven, G., Chen, J., 2004. Evolution of a hydrocarbon migration pathway along basin-bounding faults: evidence from fault cement. AAPG Bulletin 88(7), 947-970. doi: 10.1306/02090403040.

Brantley, S. L., Evans, B., Hickman, S. H., \& Crerar, D. A., 1990. Healing of microcracks in quartz: Implications for fluid flow. Geology, 18(2), 136-139.

Bruhn, R.L., Parry, W.T., Yonkee, W.A., Thompson, T., 1994. Fracturing and hydrothermal alteration in normal fault zones. Pure and Applied Geophysics 142, 609-644.

Butler, R.W.H., 2009. Cárn na Canaich. In Mendum, J.R., Barber, A.J., Butler, R.W.H., Flinn, D., Goodenough, K.M., Krabbendam, M., Park, R.G., Stewart, A.D. (Eds.), Lewisian, Torridonian and Moine Rocks of Scotland. Geological Conservation Review Series, No. 34, Joint Nature Conservation Committee, Peterborough, UK, 722 p.

Caine, J.S., Evans, J.P., Forster, C.B., 1996. Fault zone architecture and permeability structure. Geology 24(11), 1025-1028.

Caputo, R., 2010. Why joints are more abundant than faults: a conceptual model to estimate their ratio in layered carbonate rocks. Journal of Structural Geology 32(9), 1257-1270, doi:10.1016/j.jsg.2009.05.011.

Chester, F.M., Logan, J.M., 1986. Implications for mechanical properties of brittle faults from observations of the Punchbowl fault zone, California. Pure and Applied Geophysics 124(1-2), 79 106.

Childs, C., Manzocchi, T., Walsh, J.J., Bonson, C.G., Nicol, A., Schopfer, M.P.J., 2009. A geometric model of fault zone and fault rock thickness variations. Journal of Structural Geology 31(2), 117 127. doi: 10.1016/j.jsg.2008.08.009.

Cook, J.E., Dunne, W.M., Onasch, C.A., 2006. Development of a dilatant damage zone along a thrust relay in a low-porosity quartz arenite. Journal of Structural Geology 28(5), 776-792.

Crider, J.G., Peacock, D.C.P., 2004. Initiation of brittle faults in the upper crust: a review of field observations. Journal of Structural Geology 26(4), 691-707.

De Joussineau, G., Aydin A., 2007. The evolution of the damage zone with fault growth in sandstone and its multiscale characteristics. Journal of Geophysical Research-Solid Earth 112(B12), B12401.

Eichhubl, P., Davatzes, N.C., Becker, S.P., 2009. Structural and diagenetic control of fluid migration and cementation along the Moab Fault, Utah. AAPG Bulletin 93(5), 653-681.

Eichhubl, P., D’Onfro, P., Aydin, A., Waters, J., McCarty, D. K., 2005. Structure, petrophysics, and diagenesis of shale entrained along a normal fault, Black Diamond Mines, California-implications for fault seal. AAPG Bulletin 89(9), 1113-1137. 
Ellis, M.A., Laubach, S.E. Eichhubl, P., Olson, J.E., Hargrove, P., 2012. Fracture development and diagenesis of Torridon Group Applecross Formation, near An Teallach, NW Scotland: millennia of brittle deformation resilience? Journal of the Geological Society, London 169(3), 297-310. doi: 10.1144/0016-76492011-086.

Elmore, D.R., Burr, R., Engel, M., Parnell, J., 2010. Paleomagnetic dating of fracturing using breccia veins in Durness group carbonates, NW Scotland. Journal of Structural Geology 32(12), 1933-1942.

Evans, J.P., Forster C.B., Goddard J.V., 1997. Permeability of fault-related rocks, and implications for hydraulic structure of fault zones. Journal of Structural Geology 19(11), 1393-1404. doi: 10.1016/S0191-8141(97)00057-6.

Fall, A., Eichhubl, P., Cumella, S.P., Bodnar, R.J., Laubach, S.E., Becker, S.P., 2012. Testing the basincentered gas accumulation model using fluid inclusion observations: southern Piceance Basin, Colorado. AAPG Bulletin 96(12), 2297-2318. doi: 10.1306/05171211149.

Faulkner, D.R., Jackson, C.A.L., Lunn, R.J., Schlische, R.W., Shipton Z.K., Wibberley C.A.J., Withjack M.O., 2010. Review of recent developments concerning the structure, mechanics and fluid flow properties of fault zones. Journal of Structural Geology 32(11), 1557-1575. doi: 10.1016/j.jsg.2010.06.009.

Ferrill, D.A., Smart, K.J., Necsoiu, M., 2008. Displacement-length scaling for single-event fault ruptures: insights from Newberry Springs Fault Zone and implications for fault zone structure. In Wibberley, C.A.J., Kurz, W., Imber, J., Collettini, C. (Eds.), The Internal Structure of Fault Zones. Geological Society, London, Special Publication 299, 113-122. doi: 10.1144/SP299.7.

Fisher, D.M., Brantley, S.L., 2014. The role of silica redistribution in the evolution of slip instabilities along subduction interfaces: constraints from the Kodiak Accretionary Complex, Alaska. Journal of Structural Geology. doi.org/10.1016/j.jsg.2014.03.010.

Fisher, D.M., Brantley, S.L., 1992. Models of quartz overgrowth and vein formation: deformation and episodic fluid flow in an ancient subduction zone. Journal of Geophysical Research 97, 2004320061.

Fisher, Q.J., Casey, M., Harris, S.D., Knipe, R.J., 2003. Fluid flow properties of faults in sandstone: the importance of temperature history. Geology 31, 965-968.

Fisher, Q.J., Knipe, R.J., 1998. Fault sealing processes in siliciclastic sediments. Geological Society, London, Special Publication 147, 117-134. doi: 10.1144/GSL.SP.1998.147.01.08.

Fisher, Q.J., Knipe, R.J., 2001. The permeability of faults within siliciclastic petroleum reservoirs of the North Sea and Norwegian Continental Shelf. Marine \& Petroleum Geology 18, 1063-1081.

Foxford, K.A., Walsh, J.J., Watterson, J., Garden, I.R., Guscott, S.C., Burley, S.D., 1998. Structure and content of the Moab fault zone, Utah, USA, and its implications for fault seal prediction. Geological Society, London, Special Publication 147, 87-103.

Gomez, L.A., Laubach, S.E, 2006, Rapid digital quantification of microfracture populations. Journal of Structural Geology 28, 408-420. 
Goodenough, K.M., Krabbendam, M., Bradwell, T., Finlayson, A., Leslie, A.G., 2009. Digital surface models and the landscape: Interaction between bedrock and glacial geology in the Ullapool area. Scottish Journal of Geology 45, 99-105.

Hall, A., Bishop P., 2002. Timing, mechanisms and implications for petroleum exploration, Scotland's denudation history: an integrated view of erosion and sedimentation at an uplifted margin. In Dore A.G., Cartwright J.A., Stoker M.S., Turner J.P., White N. (Eds.), Exhumation of the North Atlantic Margin. Geological Society, Special Publication 196, 271-290.

Heald, M.T., Larese, R.E., 1974. Influence of coatings on quartz cementation. Journal of Sedimentary Petrology 44, 1269-1274.

Hesthammer, J., Bjørkum P.A., Watts L., 2002. The effect of temperature on sealing capacity of faults in sandstone reservoirs; examples from the Gullfaks and Gullfaks Sør fields, North Sea. AAPG Bulletin $86,1733-1751$.

Hilgers, C., Koehn, D., Bons, P.D., Urai, J.L., 2001. Development of crystal morphology during uniaxial growth in a progressively widening vein: II. Numerical simulations of the evolution of antitaxial fibrous veins. Journal of Structural Geology 23, 873-885.

Hippler, S.J., 1993. Deformation microstructures and diagenesis in sandstone adjacent to an extensional fault: implications for the flow and entrapment of hydrocarbons. AAPG Bulletin 77(4), 625-637.

Holdsworth, R.E., Butler, C.A., Roberts, A.M., 1997. The recognition of reactivation during continental deformation. Journal of the Geological Society 154(1), 73-78.

Holdsworth, R.E., Stewart, M., Imber, J., Strachan, R.A., 2001. The structure and rheological evolution of reactivated continental fault zones: a review and case study. Geological Society, London, Special Publication 184, 115-137.

Holford, S.P., Green, P.F., Hillis, R.R., Underhill, J.R., Stoker, M.S., Duddy, I.R., 2010. Multiple postCaledonian exhumation episodes across NW Scotland revealed by apatite fission-track analysis. Journal of the Geological Society 167, 675-694.

Holland, M., Urai, J.L., 2010. Evolution of anastomosing crack-seal vein networks in limestones: Insight from an exhumed high-pressure cell, Jabal Shams, Oman Mountains. Journal of Structural Geology 32(9), 1279-1290, doi:10.1016/j.jsg.2009.04.011

Hooker, J.N., Gomez, L.A., Laubach, S.E., Gale, J.F.W. Marrett, R., 2012. Effects of diagenesis (cement precipitation) during fracture opening on fracture aperture-size scaling in carbonate rocks. In Garland, J., Neilson, J.E., Laubach, S.E., Whidden, K.J. (Eds.), Advances in Carbonate Exploration and Reservoir Analysis. Geological Society of London, Special Publication 370, 187-206. doi: 10.1144/SP370.9.

Hooker, J.N., Laubach, S.E., Gomez, L., Marrett, R., Eichhubl, P., Diaz-Tushman, K., Pinzon, E., 2011. Fracture size, frequency, and strain in the Cambrian Eriboll Formation sandstones, NW Scotland. Scottish Journal of Geology 47(1), 45-56.

Hooker, J.N., Laubach, S.E., Marrett, R., 2014. A universal power-law scaling exponent for fracture apertures in sandstone. Geological Society of America Bulletin. doi: 10.1130/B30945.1. 
Hooker, J.N., Laubach, S.E., Marrett, R., 2013. Fracture-aperture size-frequency, spatial distribution, and growth processes in strata-bounded and non-strata-bounded fractures, Cambrian Mesón Group, NW Argentina. Journal of Structural Geology 54, 54-71. doi: 10.1016/j.jsg.2013.06.011.

Hu, C., Cai, Y., Liu, M, Wang, Z., 2013. Aftershock due to property variations in the fault zone: a mechanical model. Tectonophysics 588, 179-188. doi: 10.1016/j.tecto.2012.12.013.

Hudson, J.D., 2011. Multiple post-Caledonian exhumation episodes across NW Scotland revealed by apatite fission-track analysis; discussion. Journal of the Geological Society of London 168(5), 12251226.

Johansen, T.E.S., Fossen, H., 2008. Internal geometry of fault damage zones in interbedded siliciclasic sediemnts. In Wibberley, C.A.J., Kurz, W., Imber, J., Collettini, C. (Eds.), The Internal Structure of Fault Zones. Geological Society, London, Special Publication 299, 35-56. doi: 10.1144/SP299.3.

Johnson, M.R.W., Kelley, S.P., Oliver, G.J.H., Winter, D.A., 1985. Thermal effects and the timing of thrusting in the Moine Thrust Zone. Journal of the Geological Society 142, 863-874.

Johnstone, G.S., Mykura, W., 1989. British Regional Geology: The Northern Highlands of Scotland, 4th Edition. HMSO, London.

Kim, Y.S., Peacock, D.C.P., Sanderson, D.J., 2004. Fault damage zones. Journal of Structural Geology 26, 503-517.

Kim, Y.S., Sanderson, D.J., 2005. The relationship between displacement and length of faults: a review. Earth-Science Reviews 68(3), 317-334.

Kinnaird, T.C., Prave, A.R., Kirkland, C.L., Horstwood, M., Parrish, R., Batchelor, R.A., 2007. The late Mesoproterozoic-early Neoproterozoic tectonostratigraphic evolution of NW Scotland: the Torridonian revisited. Journal of the Geological Society 164(3), 541-551.

Knipe, R.J., Lloyd, G.E., 1994. Microstructural analysis of faulting in quartzite, Assynt, NW Scotland: implications for fault zone evolution. Pure and Applied Geophysics 143(1-3), 229-254.

Krabbendam, M., Glasser, N.F., 2011. Glacial erosion and bedrock properties in NW Scotland: abrasion and plucking, hardness and joint spacing. Geomorphology 130, 374-383.

Labaume, P., Moretti, I., 2001. Diagenesis-dependence of cataclastic thrust fault zone sealing in sandstones: example from the Bolivian sub-Andean zone. Journal of Structural Geology 23(11), $1659-1675$.

Lander, R.H., Larese, R.E., Bonnell, L.M., 2008. Toward more accurate quartz cement models - the importance of euhedral vs. non-euhedral growth rates. AAPG Bulletin 92, 1537-1564.

Lander, R.H., Laubach, S.E., 2014. Insights into rates of fracture growth and sealing from a model for quartz cementation in fractured sandstones. GSA Bulletin. doi:

Lander, R.H., Walderhaug, O., 1999. Porosity prediction through simulation of sandstone compaction and quartz cementation. AAPG Bulletin 83, 433-449.

Laubach, S.E., Diaz-Tushman, K., 2009. Laurentian paleostress trajectories and ephemeral fracture permeability, Cambrian Eriboll Formation sandstones west of the Moine thrust zone, northwest 
Scotland. Journal of the Geological Society, London 166, 349-362. doi: 10.1144/0016-76492008061.

Laubach, S.E., Eichhubl, P., Hilgers, C., Lander, R.H., 2010. Structural diagenesis. Journal of Structural Geology 32(12), 1866-1872. doi:10.1016/j.jsg.2010.10.001

Laubach, S.E., Marshak, S., 1987. Fault patterns generated during extensional deformation of crystalline basement, NW Scotland. In Coward M.P., Dewey J.F., Hancock P.L. (Eds.), Continental Extensional Tectonics, Geological Society, London, Special Publication 28, 495-499.

Laubach, S.E., Olson, J.E, Gross, M.R., 2009. Mechanical and fracture stratigraphy. AAPG Bulletin 93(11), 1413-1426. doi: 10.1306/07270909094

Laubach, S.E., Reed, R.M., Olson, J.E., Lander, R.H., Bonnell, L.M., 2004. Coevolution of crack-seal texture and fracture porosity in sedimentary rocks: cathodoluminescence observations of regional fractures. Journal of Structural Geology 26(5), 967-982.

Long, J.J., Imber J., 2010. Geometrically coherent continuous deformation in the volume surrounding a seismically imaged normal fault-array. Journal of Structural Geology 32(2), 222-234. doi: 10.1016/j.jsg.2009.11.009.

Long, J., Witherspoon, P.A., 1985. The relationship of the degree of interconnection to permeability in fracture networks. Journal of Geophysical Research: Solid Earth 90(B4), 3087-3098.

Lunn, R.J., Shipton, Z.K., Bright, A.M., 2008. How can we improve estimates of bulk fault zone hydraulic properties? In Wibberley, C.A.J., Kurz, W., Imber, J., Collettini, C. (Eds.), The Internal Structure of Fault Zones. Geological Society, London, Special Publication 299, 231-237. doi: 10.1144/SP299.14.

Macdonald, D.I.M., Archer, B., Murray, S., Smith, K., Bates, A., 2007. Modelling and comparing the Caledonian and Permo-Triassic erosion surfaces across Highland Scotland implications for landscape inheritance. In Nichols G., Williams E., Paola C. (Eds.), Sedimentary Processes, Environments and Basins. International Association of Sedimentologists Special Publication 38, 283-299.

Manzocchi, T., Childs, C., Walsh, J.J., 2010. Faults and fault properties in hydrocarbon flow models. Geofluids 10(1-2), 94-113.

Marrett, R., 1996. Aggregate properties of fracture populations. Journal of Structural Geology 18(2-3), 169-178.

Marrett, R., Ortega, O.O., Kelsey, C., 1999. Extent of power-law scaling of natural fractures in rock. Geology 27, 799-802.

Mauldon, M., Dunne, W. M., Rohrbaugh Jr, M. B., 2001. Circular scanlines and circular windows: new tools for characterizing the geometry of fracture traces. Journal of Structural Geology 23(2), 247258.

McBride, E.F., 1989. Quartz cement in sandstones: a review. Earth-Science Reviews 26, 69-112.

McGrath, A.G., Davison, I., 1995. Damage zone geometry around fault tips. Journal of Structural Geology 17(7), 1011-1024. 
Mitchell, T.M., Faulkner, D.R., 2009. The nature and origin of off-fault damage surrounding strike-slip fault zones with a wide range of displacements: a field study from the Atacama fault system, northern Chile. Journal of Structural Geology 31(8), 802-816.

Mizoguchi, K., Hirose, T., Shimamoto, T., Fukuyama, E., 2008, Internal structure and permeability of the Nojima fault, southwest Japan. Journal of Structural Geology 30(4), 513-524.

Olson, J.E., 2003. Sublinear scaling of fracture aperture versus length: an exception of the rule? Journal of Geophysical Research-Solid Earth 108(B9), 2413. doi: 10.1029/2001JB000419.

Olson, J.E, Laubach, S.E., Lander, R.H., 2009. Natural fracture characterization in tight gas sandstones: integrating mechanics and diagenesis. AAPG Bulletin 93, 1535-1549. doi: 10.1306/08110909100

Ortega, O.J., Marrett, R., Laubach, S.E., 2006. A scale-independent approach to fracture intensity and average spacing measurement. AAPG Bulletin 90(2), 193-208. doi: 10.1306/08250505059

Ortega, O.O., Marrett, R., 2000. Prediction of macrofracture properties using microfracture information, Mesaverde Group sandstones, San Juan Basin, New Mexico. Journal of Structural Geology 22, 571588.

Park, R.G., Stewart, A.D., Wright, D.T., 2002. The Hebridean terrane. In Trewin, N.H. (Ed.) The Geology of Scotland. The Geological Society, London, 45-81.

Peach, B.N, Horne, J., Gunn, W., Clough, C.T., Hinxman, L. W., Teall, J.J., 1907. The Geological Structure of the Northwest Highlands of Scotland. Memoirs of the Geological Survey, U.K.

Petrie, E.S., Petrie, R.A., Evans, J.P., 2014. Identification of reactivation and increased permeability associated with a fault damage zone using a multidisciplinary approach. Journal of Structural Geology 59, 37-49.

Philip, Z.G., Jennings, J.W., Jr., Olson, J., Laubach, S.E., Holder, J., 2005, Modeling coupled fracturematrix fluid flow in geomechanically simulated fracture networks. SPE Reservoir Evaluation \& Engineering 8(4), 300-309.

Questiaux, J.M., Couples, G.D., Ruby, N., 2010. Fractured reservoirs with fracture corridors. Geophysical Prospecting 58(2), 279-295.

Rawling, G.C., Goodwin, L.B., Wilson, J.L., 2001. Internal architecture, permeability structure, and hydrologic significance of contrasting fault-zone types. Geology 29(1), 43-46.

Roberts, A.M., Holdsworth, R.E., 1999. Linking onshore and offshore structures: Mesozoic extension in the Scottish Highlands. Journal of the Geological Society, London 156, 1061-1064.

Shipton, Z.K., Cowie, P.A., 2003. A conceptual model for the origin of fault damage zone structures in high-porosity sandstone. Journal of Structural Geology 25, 333-344.

Shipton, Z.K., Evans, J.P., Robeson, K.R., Forster, C.B., Snelgrove, S.S., 2002. Structural heterogeneity and permeability in faulted eolian sandstone: implications for subsurface modeling of faults. AAPG Bulletin 86(5), 863-883.

Shipton, Z.K., Soden, A.M., Kirkpatrick, J.D., Bright, A.M., Lunn, R.J., 2006. How thick is a fault? Fault displacement-thickness scaling revisited. Geophysical Monograph Series 170, 193-198. 
Sibson, R.H., 1985. Stopping of earthquake ruptures at dilational fault jogs. Nature 316, 248-251.

Sibson, R.H., Moore, J., Rankin, A.H., 1975. Seismic pumping - a hydrothermal fluid transport mechanism. Journal of the Geological Society, London 131, 653-659.

Stewart, A.D., 1996. Late Proterozoic and late Palaeozoic movement on the Coigash fault in NW Scotland. Scottish Journal of Geology 29(1), 21-28.

Stewart, A.D., 2002. The Later Proterozoic Torridonian Rocks of Scotland: their Sedimentology, Geochemistry and Origin. Geological Society Memoir No. 24, 130 p.

Taylor, T.R., Giles, M.R., Hathon, L.A., Diggs, T.N., Braunsdorf, N.R., Birbiglia, G.V., Kittridge, M.G., Macaulay, C.I., Espejo, I.S., 2010. Sandstone diagenesis and reservoir quality prediction: models, myths, and reality. AAPG Bulletin 94, 1093-1132. doi: 10.1306/04211009123.

Trewin, N.H., Rollin, K.E., 2002. Geologic history and structure of Scotland. In Trewin, N.H. (Ed.) The Geology of Scotland. The Geological Society, London, 1-25.

van der Zee, W., Wibberley, C.A.J., Urai J.L., 2008. The influence of layering and pre-existing joints on the development of internal structure in normal fault zones: the Lodève basin, France. In Wibberley, C.A.J., Kurz, W., Imber, J., Collettini, C. (Eds.), The Internal Structure of Fault Zones. Geological Society, London, Special Publication 299, 57-74. doi: 10.1144/SP299.4.

Vermilye, J.M., Scholz, C.H., 1995. Relation between vein length and aperture. Journal of Structural Geology 17(3), 423-434.

Virgo, S., Abe, S., Urai, J.L., 2013. Extension fracture propagation in rocks with veins: insight into the crack-seal process using Discrete Element Method modeling. J. Geophys. Res. Solid Earth, 118, 5236-5251, doi:10.1002/2013JB010540

Walderhaug, O., 1996. Kinetic modeling of quartz cementation and porosity loss in deeply buried sandstone reservoirs: AAPG Bulletin 80, 731-745.

Walderhaug, O., 2000. Modeling quartz cementation and porosity loss in Middle Jurassic Brent Group sandstones of the Kvitebjørn field, northern North Sea. AAPG Bulletin 84, 1325-1339.

Walderhaug, O., Lander, R.H., Bjørkum, P.A., Oelkers, E.H., Bjørlykke, K., Nadeau, P.H., 2000. Modeling quartz cementation and porosity in reservoir sandstones - examples from the Norwegian continental shelf. In Worden, R.H., Morad, S. (Eds.), Quartz Cementation in Sandstones. International Association of Sedimentologists Special Publication 29, 39-49.

Walsh, J.J., Nicol, A., Childs, C., 2002. An alternative model for the growth of faults. Journal of Structural Geology 24(11), 1669-1675.

Wibberley, C.A.J., Yielding, G., Di Toro, G., 2008. Recent advances in the understanding of fault zone internal structure: a review. In Wibberley, C.A.J., Kurz, W., Imber, J., Collettini, C. (Eds.), The Internal Structure of Fault Zones. Geological Society, London, Special Publication 299, 5-33. doi: 10.1144/SP299.2.

Willemse, E.J., Pollard, D.D., 1998. On the orientation and patterns of wing cracks and solution surfaces at the tips of a sliding flaw or fault. Journal of Geophysical Research, Solid Earth 103(B2), 24272438 . 
Williams, G.E., Foden, J., 2011. A unifying model for the Torridon Group (early Neoproterozoic), NW Scotland: product of post-Grenvillian extensional collapse. Earth-Science Reviews 108, 34-49.

Wilson, R.W., Holdsworth, R.E., Wild, L.E., McCaffrey, K.J.W., England, R.W., Imber, J., Strachan, R.A., 2010. Basement-influenced rifting and basin development: a reappraisal of post-Caledonian faulting patterns from the North Coast Transfer Zone, Scotland. In Law, R., Butler, R.W.H., Strachan, R.A., Krabbendam, M. (Eds.), Continental Tectonics and Mountain Building: The Legacy of Peach and Horne. Geological Society, London, Special Publication 335, 795-826.

Woodcock, N.H., Dickson, J.A.D., Tarasewicz, J.P.T., 2007. Transient permeability and reseal hardening in fault zones: evidence from dilation breccia textures. Geological Society, London, Special Publication 270, 43-53.

Woodcock, N.H., Mort, K., 2008. Classification of fault breccias and related fault rocks. Geological Magazine 145(3), 435-440. 


\section{Figures}

Fig. 1. Location map and fault traces. Bedrock geology and hill-shaded digital surface model (British Geological Survey). Geology and fault traces adapted from Peach et al., 1909; Goodenough et al., 2008; this study. Fa, Corrie Hallie and Gleann Chaorachain faults; $\mathrm{F} b$, Brathan fault. Inset: location of field area in Scotland.

Fig. 2. Fault exposures. (a) Fault Fa locality, view E from An Teallach. Ax, Applecross Formation; E, Eriboll Formation. Part of contact (blue) and fault trace (red) indicated. Outlinebox marks tents showing scale. Corrie Hallie (Fal) and Gleann Chaorachain (Fa2) faults. Location of Fig. 12 marked. (b) Air photograph showing faults $\mathrm{F} a, \mathrm{~F} b$; source: GoogleEarth. Location of Fig. 12 marked. (c) Close-up of F1a showing selected Eriboll Fomration fracture scanline results. Numbers are fractrues/meter. Red, damage zone; green, background. North is top of image in b, c. (d) Oblique striations on Eriboll Formation fault surfaces near Fal [NH103 84701] view NW; dashed line marks striae; (e) Near F $b$ [NH08880 82472] view SE, dashed line marks striae; (f) fault $m f-1$ south of $\mathrm{F} b$, view $\mathrm{NW}$, dashed line marks striae.

Fig. 3. Applecross Formation fault core, view ENE from minor fault near fault $\mathrm{F} b$ [NH 08087 80731]. (a) Red lines mark opening-mode fracture traces. Blue arrow marks north edge of cataclasite (classification of Woodcock and Mort, 2008) and corresponds in location to arrow in $\mathrm{b}$ (close up image). $\mathrm{S}$ and box marks sample shown in Figure 4. Compass is $7.6 \mathrm{~cm}$ wide.

Fig. 4. Applecross Formation cataclasite (indurated gouge) textures and textural zones G1-G3. Long dimension of image is parallel to ENE fault trace in figure 3. Plan view. Representative sample. (a) Transmitted light image; texture zones G1-G3 labeled. Blue=porosity. (b) Transmitted light with texture zones G1-G3 indicated. G1, Slightly deformed with sedimentary bedding visible or dispersed fabrics composed of discrete microfractures. Visible fragments are 30 to 50 percent of rock (1/3 to 1/2 of grains fractured); no penetrative foliation, but G1 rock has preferred orientations of transgranular microfractures in quartz grains and is subdivided by lensshaped zones separated by more comminuted rock of G2 and G3. G2, moderately deformed, light-colored, extensive breakage with 50 to 100 percent of grains broken to some extent, grain particle fabrics, and local (cm-scale) narrow ( $\mathrm{mm}$ to $\mathrm{cm}$ ) lens-shaped zones of G3. Some lensshaped zones are slightly asymmetric (s-shaped), but lack lineation. Dark-colored (clay rich) G3 10 to 50 percent matrix; unfractured grains rare, possible bimodal size distribution (concentrated survivor grains). Note that contacts between mostly intact sandstone G1 and comminuted fault rock are abrupt whereas textural transitions between different degrees of grain comminution are locally gradational. (c) Particle-size histograms for zones G1-G3 showing grain and particle size.

Fig. 5. Applecross Formation fault rock. (A) Element map (K, Al, Si, Fe). (B) Backscatter image. (C) Color CL image. $\mathrm{G}$ in all images marks an intact grain. Bar is 100 microns. Fault 
zone parallel to long dimension of figure. Although Applecross Formation fault rocks locally have low aluminosilicate content, as in this example, greater clay content associated with deformed lithic grains is widespread. These fine-grained cataclasites are not phyllosiliateframework fault rocks in the sense of Fisher and Knipe (1998).

Fig. 6. Eriboll Formation fault rock, near Fault Fb [NH08880 82472] (a) Quartz breccia, qb; dense, fault rock, fr. Striations present but not visible in this view. Host rock, hr, in damage zone. View ENE. Lens cap $3 \mathrm{~cm}$ for scale. (b) Close-up of contact in a; fc, edge of porous fault core. View ENE. Lens cap $3 \mathrm{~cm}$ for scale.

Fig. 7. Eriboll Formation fault-rock at separate locations near Fault Fb. (a) Tapering porous breccia and cataclasite with red-stained bands parallel to the fault margin. View NE. Dots mark breccia margins. (b) Red-stained quartz-cemented breccia. Compass for scale. (c) Quartzcemented breccia sample; note thin-section chips, $5 \mathrm{~cm}$ long. In upper part of sample, wall rock and clasts highlighted (blue). 1, 2 fault core margin. 3, fault core. (d) Porous breccia fault core. $\mathrm{NE}$, top of image. $\mathrm{Cm}$ scale. Dots mark breccia margins.

Fig. 8. Eriboll Formation fault-core breccia. (a) Panchromatic CL mosaic showing microfractures, grain offsets, grain-size reduction, quartz cement, and porosity. Fault Fa. Inset shows location of (b) close-up. Bar, 200 microns. (b) Close-up showing fractured grains, particle-size range. Bar, 200 microns. (c) Color CL image and map from Fault Fb. G, quartz grain (red in map); P, porosity (green in CL image, white in map); Qs, syn-fault movement quartz (blue in CL image and map); Yellow indicates pre-fault quartz cement and cement fragments. Bar, 100 microns. (d) Color CL showing quartz-lined vug porosity (P) and multiple, partly cross-cutting microfractures marking crack-seal process, evidence for syn-fault movement precipitation in Fault Fb sample. Note offset grains. Bar, 200 microns.

Fig. 9. Eriboll Formation fault-related fractures on centimeter scale for minor fault $m f-1$ south of Fault Fal, interpreted to represent incipient fault core and damage zone [NH 10836 84219]. (a) Field image, bed surface with fractures annotated. Arrow indicates North. Fractures, color key: blue, opening mode, no macroscopically visible slip; light red, mm-scale slip. Green and dark red, older fracture sets. Areas with fine-scale breccia are marked by numerous small fractures (not all traced), marking incipient isolated fault cores (cf. blue zones in figure 10). (b) Fracture map. Br, and dark blue pattern, incipient microbreccia, fault core. Light blue, incipient damage zone. Pattern reflects linkage of wing cracks, formed by stresses concentrated near the preexisting fracture tips owing to sliding along preexisting fractures. Wing cracks are generally oriented oblique to preexisting fractures.

Fig. 10. Eriboll Formation fault core and damage zone on meter scale. Minor fault $m f-2$ south of Fa2 [NH 09722 83331]. (a) Field image, bed surface with fractures, fault core and damage zone indicated. Pre-existing set A fracture, Sa. Cov, areas obscured by plant cover. (b) Fracture and 
fault-rock type map. Red lines, fracture traces. Dark blue, fault core (breccia). Light blue, Damage zone marked by abrupt decrease in fracture abundance. Arrow indicates North.

Fig. 11. Fracture abundance from selected scanlines inside and outside damage zones (DZ) sorted by intensity. (a) Eriboll Formation. Only macroscopic fractures were counted although microfractures are present. Light blue, background abundance (fault-related set D, E only). Dark blue, damage zone. Intensity variability outside of damage zones is evident from scanlines 4 to 9 . (b) Applecross Formation. All macroscopic fractures counted. Petrography shows microfractures are rare. Light red, background abundance (fault-related set L). Dark red, damage zone. Vertical lines mark median intensity (all scanlines).

Fig. 12. Applecross Formation damage-zone fracture occurrence and length, fault $\mathrm{F} a$ [NH 09628 83946]. (a) Distance-fracture length transect across fault core. (b) Damage zone en echelon opening-mode fracture traces on bedding. Note discolored (lighter) halo around fracture traces. Near fault shown in figure 4, SE of Fault F $b$ [NH 07834 80617]. (c) Trace-length histogram (average length value is between 1 and $3 \mathrm{~m}$ ). Toward the outer edge of damage zones away from fault cores, length and abundance tend to decrease gradually; patterns are not necessarily symmetric around fault cores.

Fig. 13. Quartz cement in damage-zone fractures. (a) Eriboll Formation. Note complete quartzcement coverage on fracture surfaces. Fs, sealed microfractures. P, porosity; J, linked fracture segments. Modified from Laubach and Diaz-Tushman, 2009; (b) Eriboll Formation. Cs, crackseal texture. J, linked fracture segments. Fs, microfracture, quartz filled. Pt, trace porosity (highlighted, blue), where microfracture crosses feldspar grain and cement. G, grain. CL images: Authigenic fracture quartz in fractures is dark blue; P, porosity. (c) Applecross Formation. Quartz accumulation is inhibited on feldspar and lithic grains but preferentially occurs on fractured quartz substrates. Note lack of quartz, except locally, Q, where several quartz grains are bisected by fracture. Porosity $\mathrm{P}$ adjacent to feldspar, Fsp, and lithic, L, grains.

Fig. 14. Fracture length comparison for damage zone fractures. Trace length histograms: Eriboll Formation, length distribution in narrow damage zones $x$, y differing in width and amount of slip, (a) zone about $10 \mathrm{~cm}$ wide; (b) zone about $1 \mathrm{~m}$ wide. Near NH 0972283331 and NH 09722 83331 respectively. Longer fractures are present in wider damage zones but distributions are not well exposed. Eriboll Formation fractures have a wide size range. (b) Applecross Formation fractures tend to have lengths of meters or more with a smaller size range.

Fig. 15. Kinematic aperture-size distributions, opening-mode fractures, damage zones. Blue, Eriboll Formation, power-law kinematic-aperture distribution (Hooker et al., 2011). Grey symbols are other Eriboll Formation samples/data sets, showing range of microfracture intensity. Red, Applecross Formation, size-restricted size distribution. Apertures of a few of the widest fractures in the Applecross Formation have been exaggerated by weathering. Vertical lines are based on Eriboll sandstone CL quartz-cement thickness measurements and correspond to fracture 
aperture size at which porosity is widespread (emergent threshold): ETv, cement thickness lining open core-zone vugs; ETi, cement thickness lining open damage-zone fractures.

Table 1 Fault-core and damage-zone attributes of late faults. 


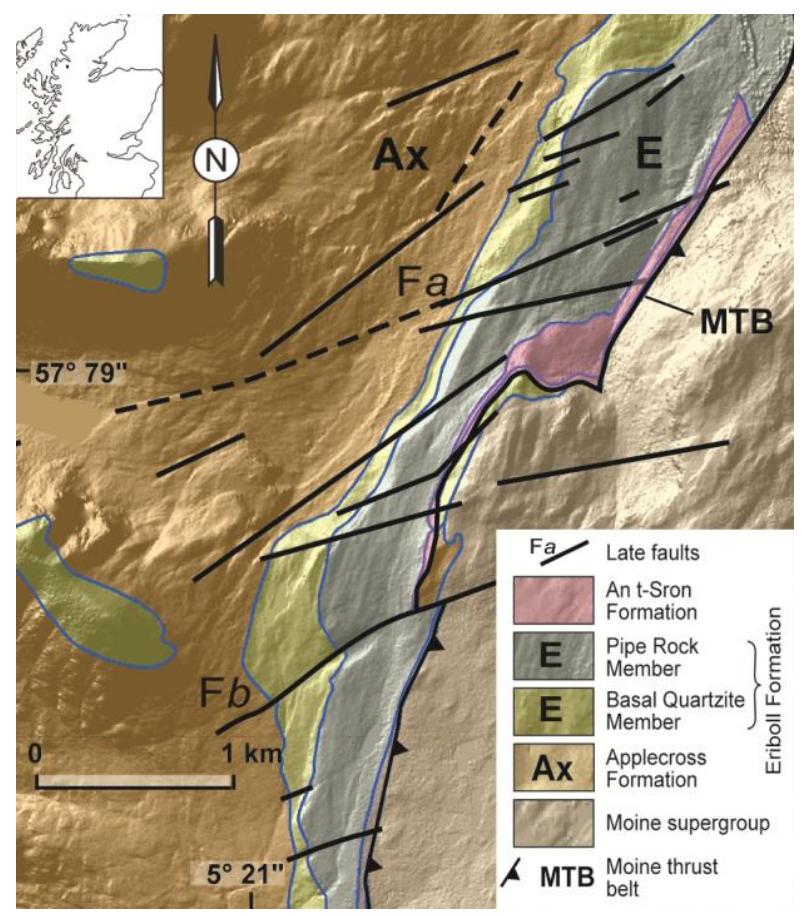




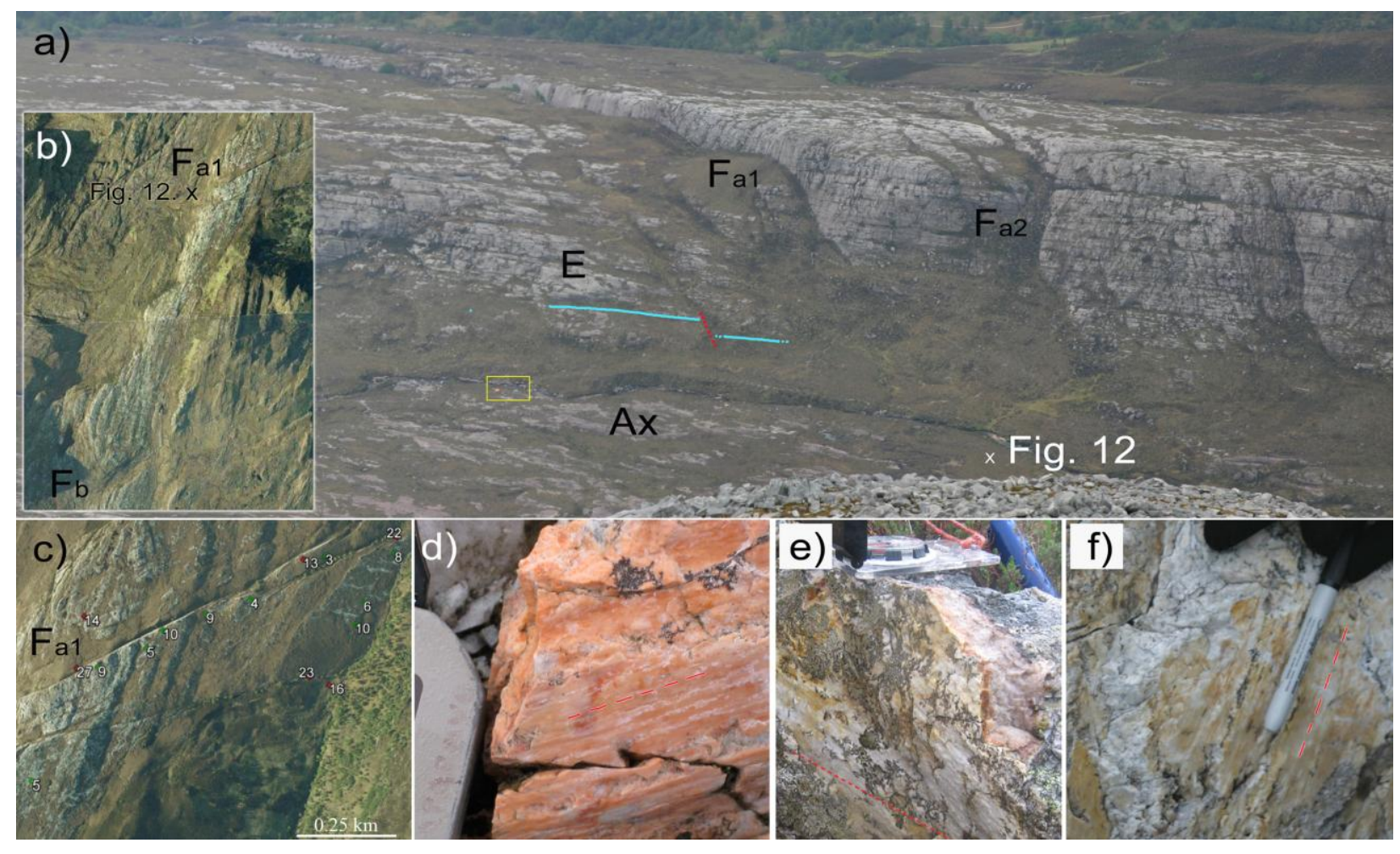



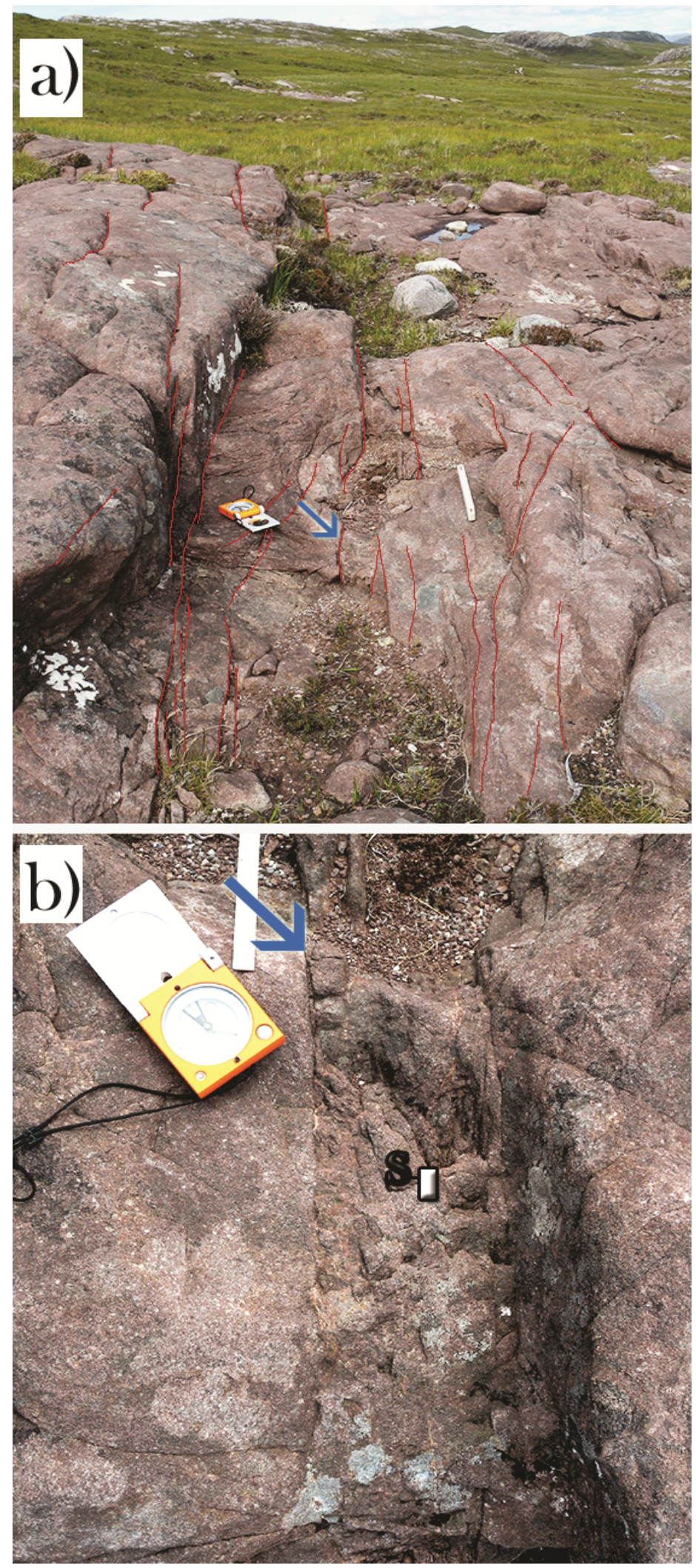


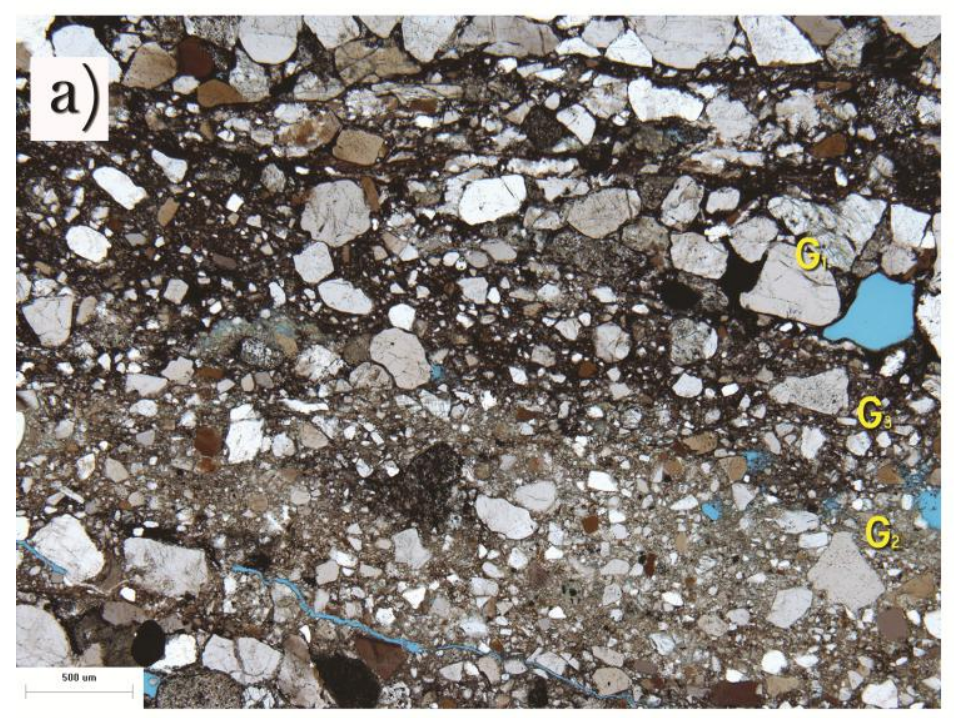

c)
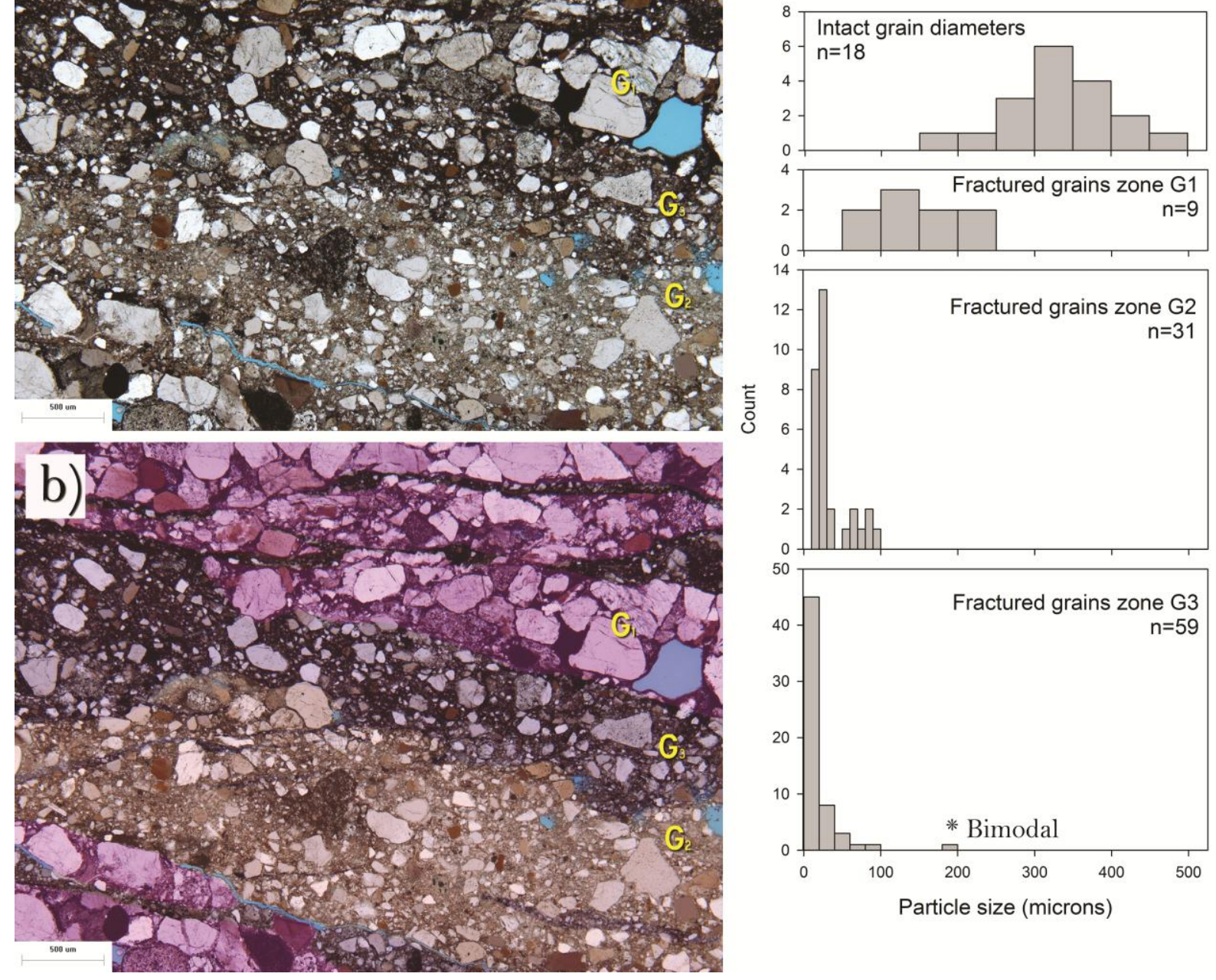

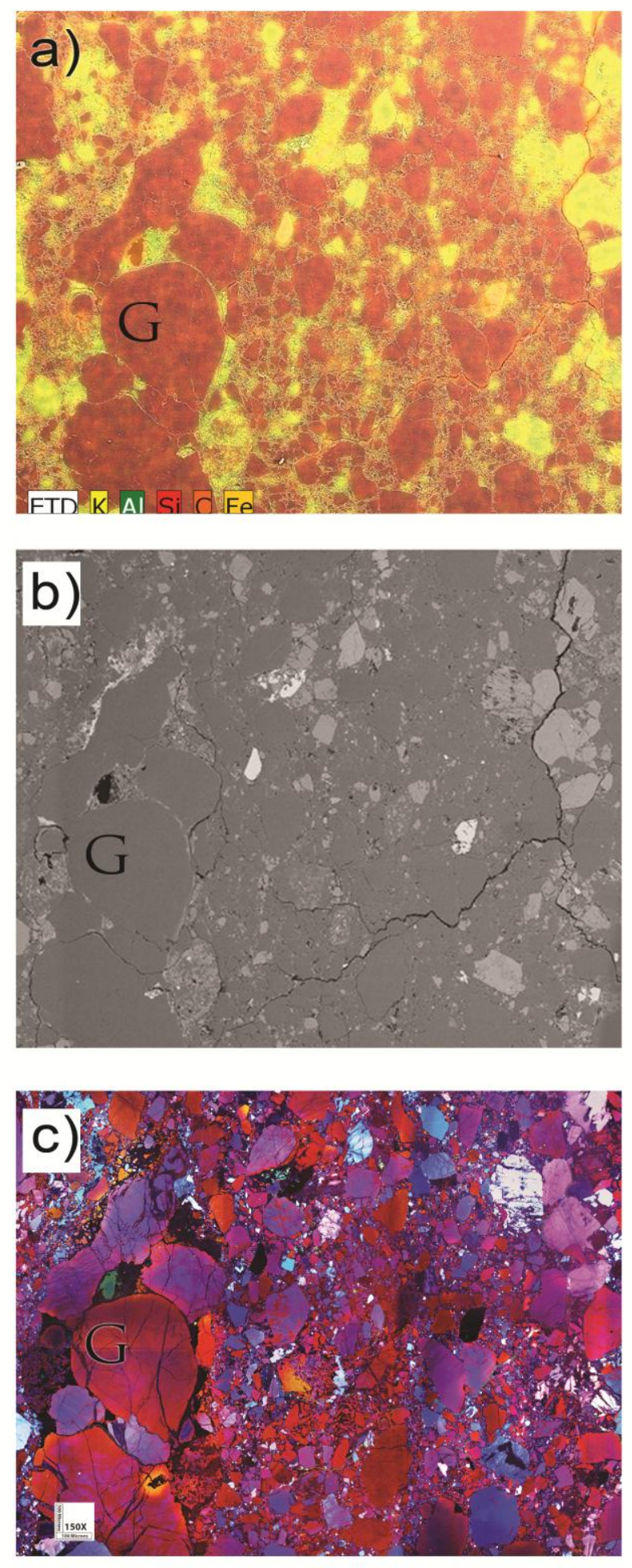

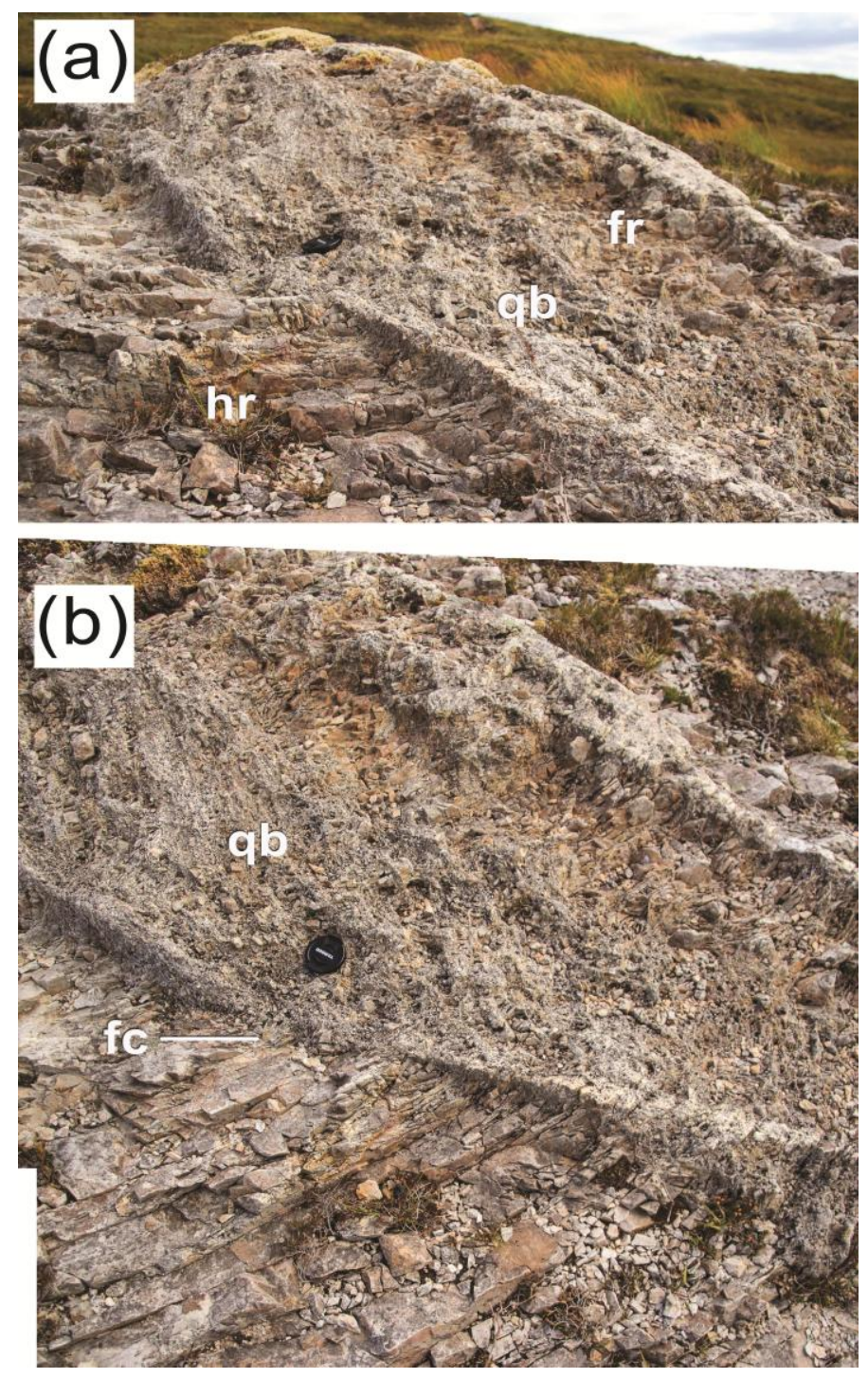

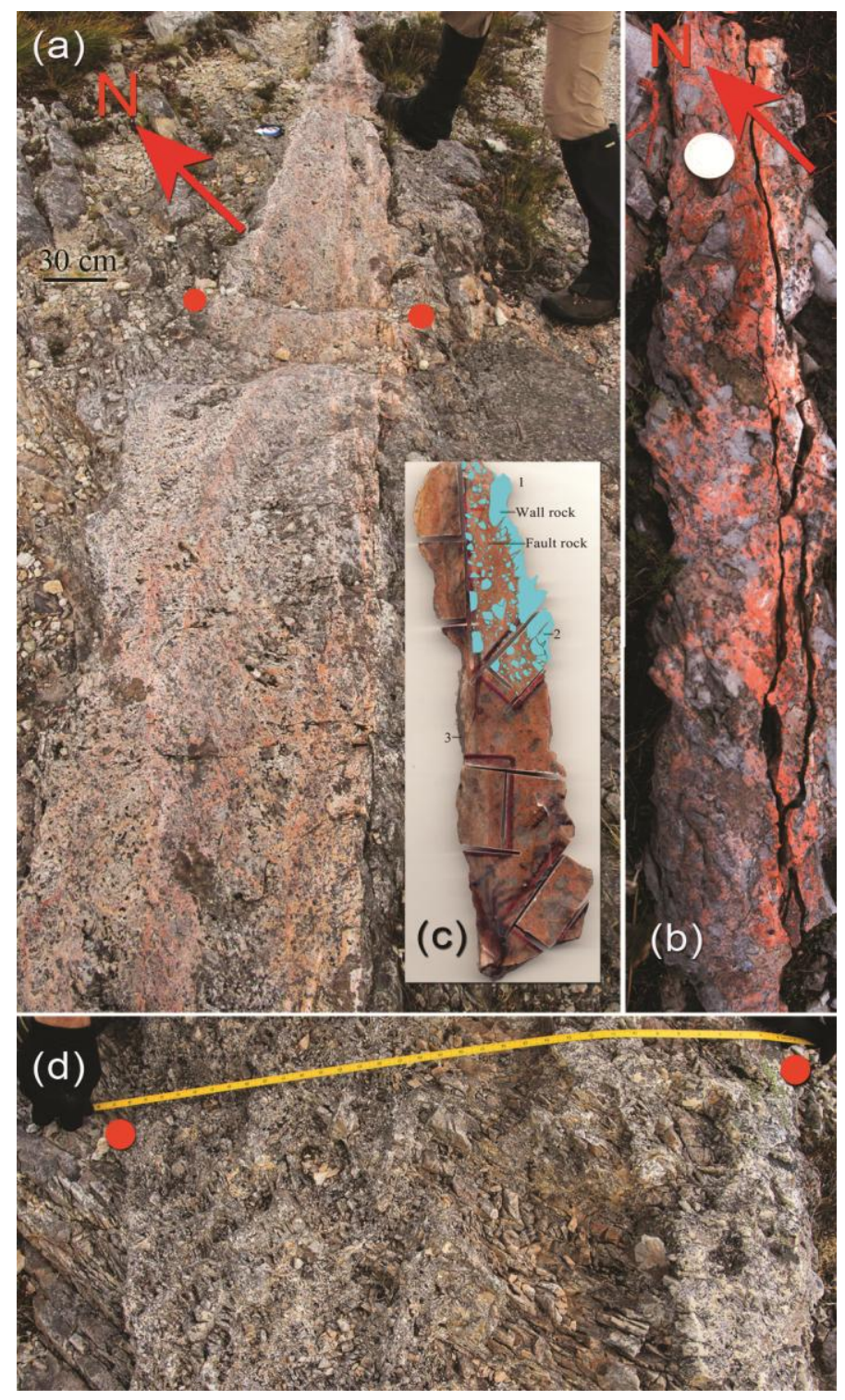

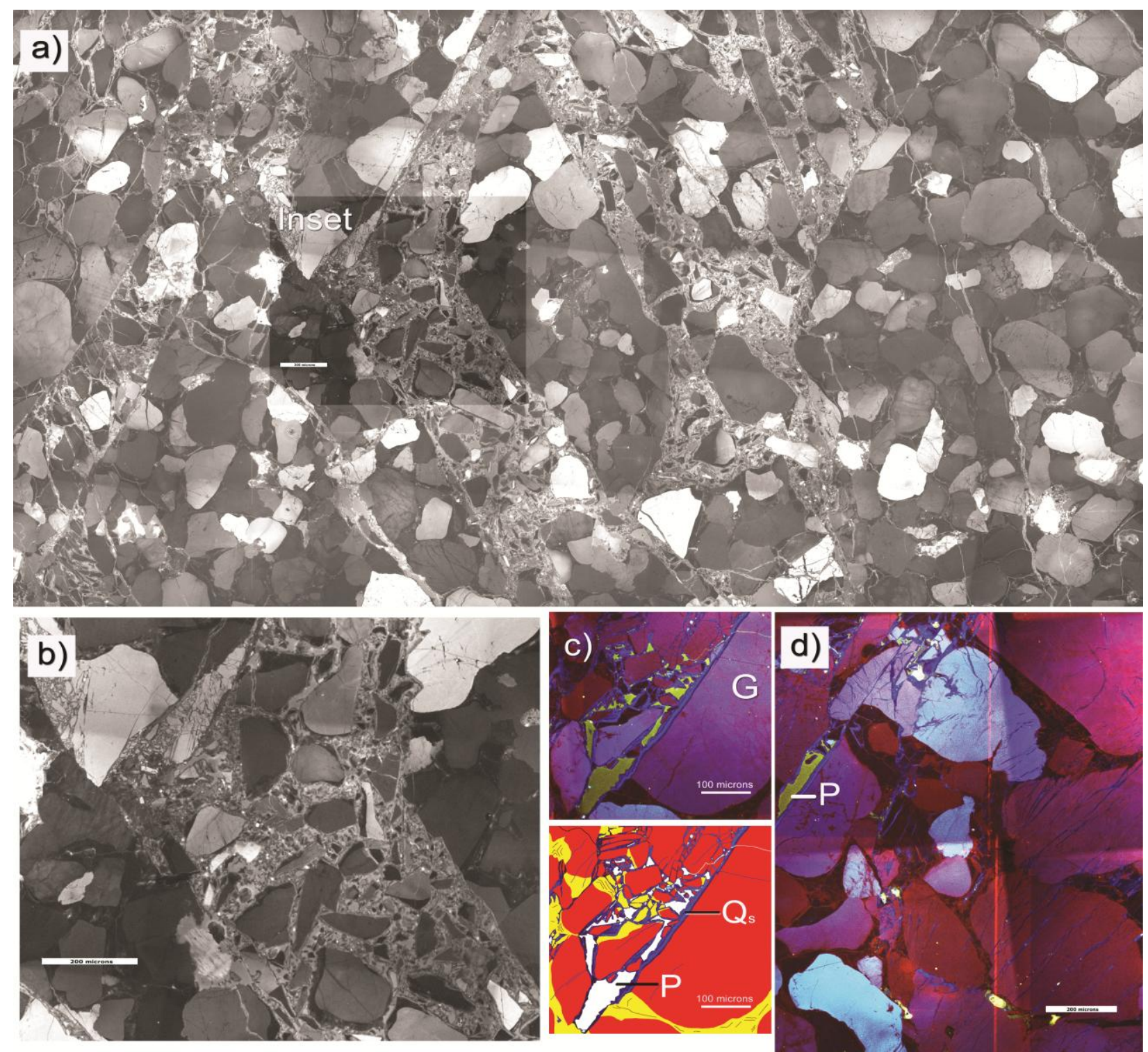


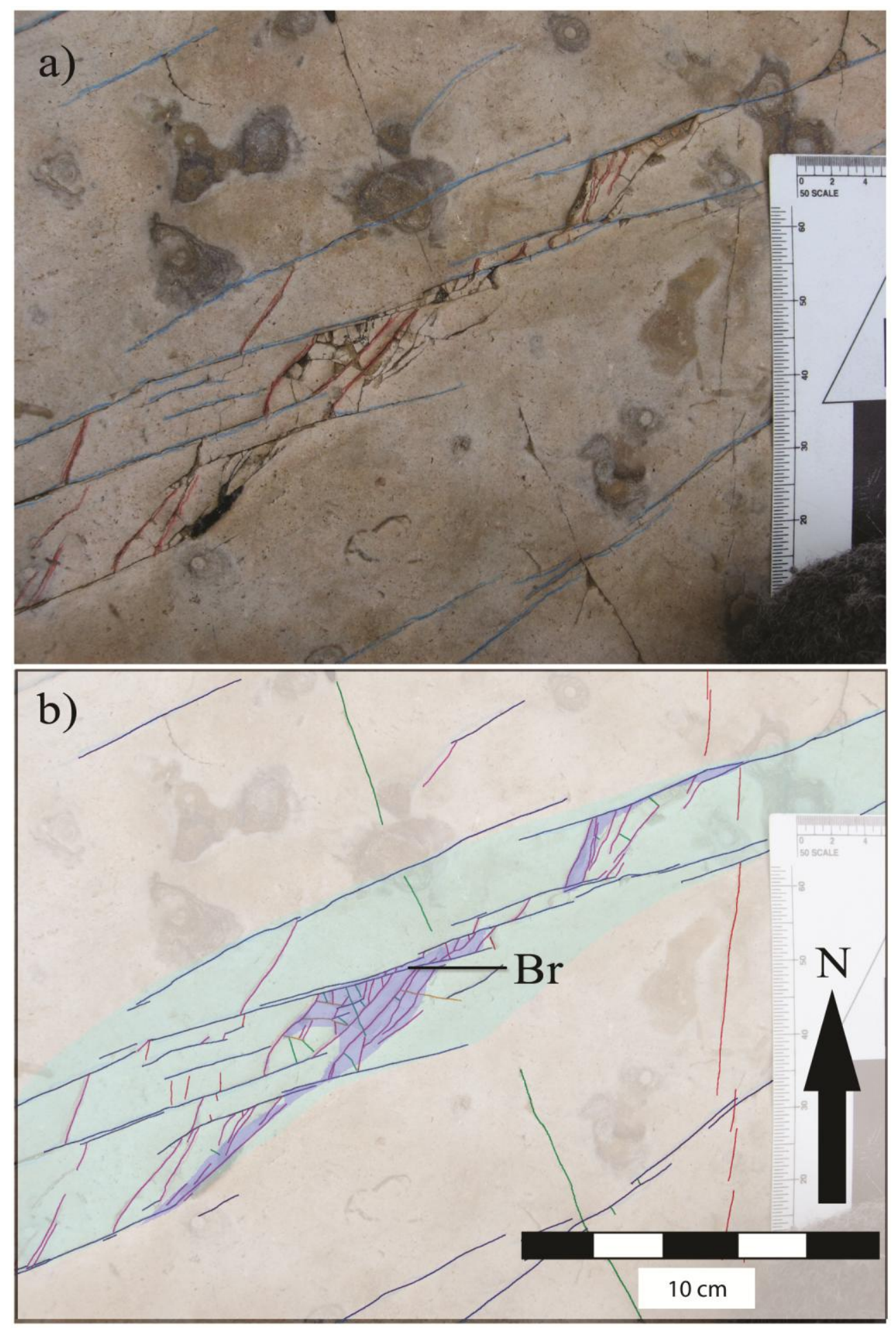



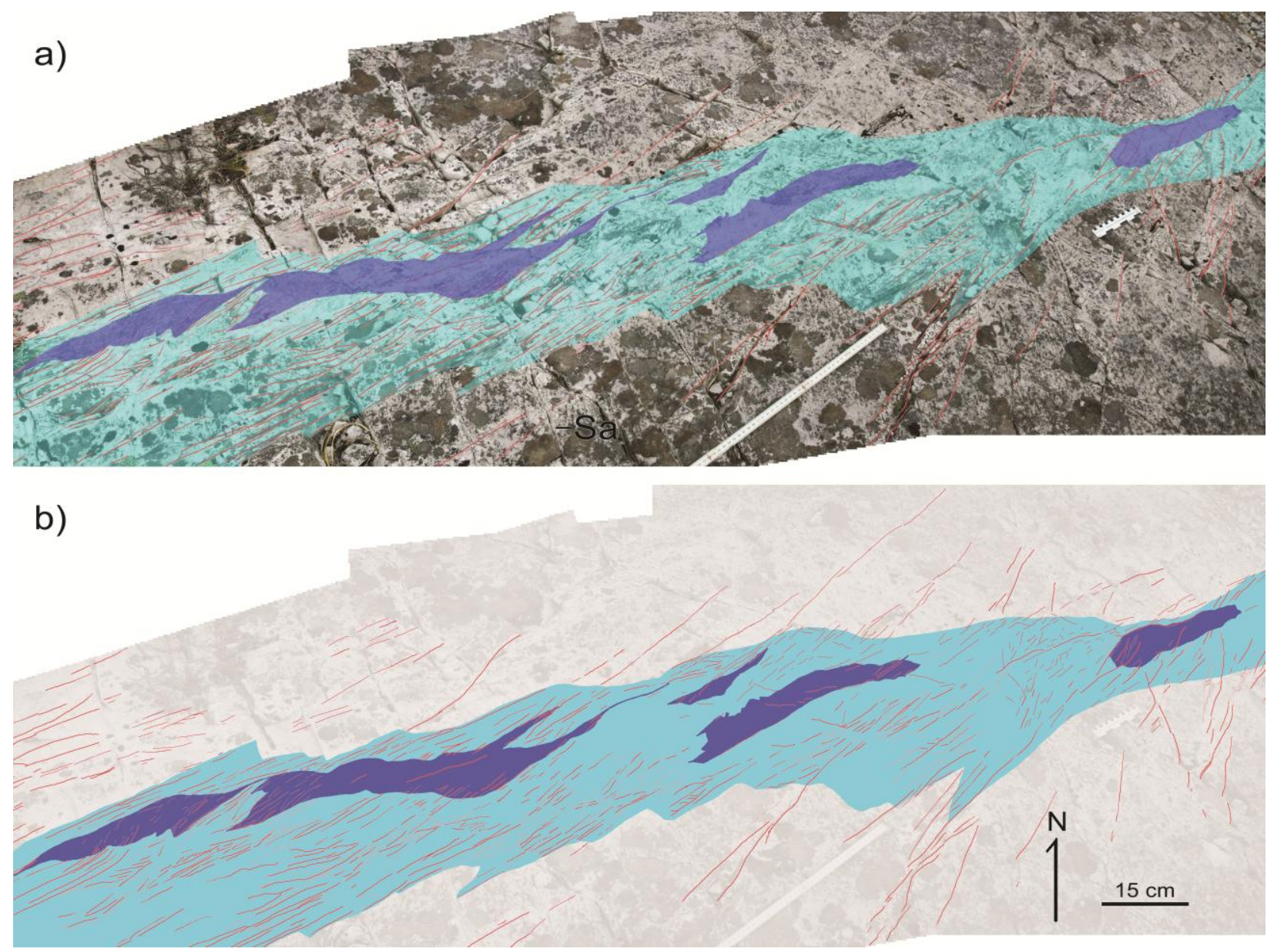

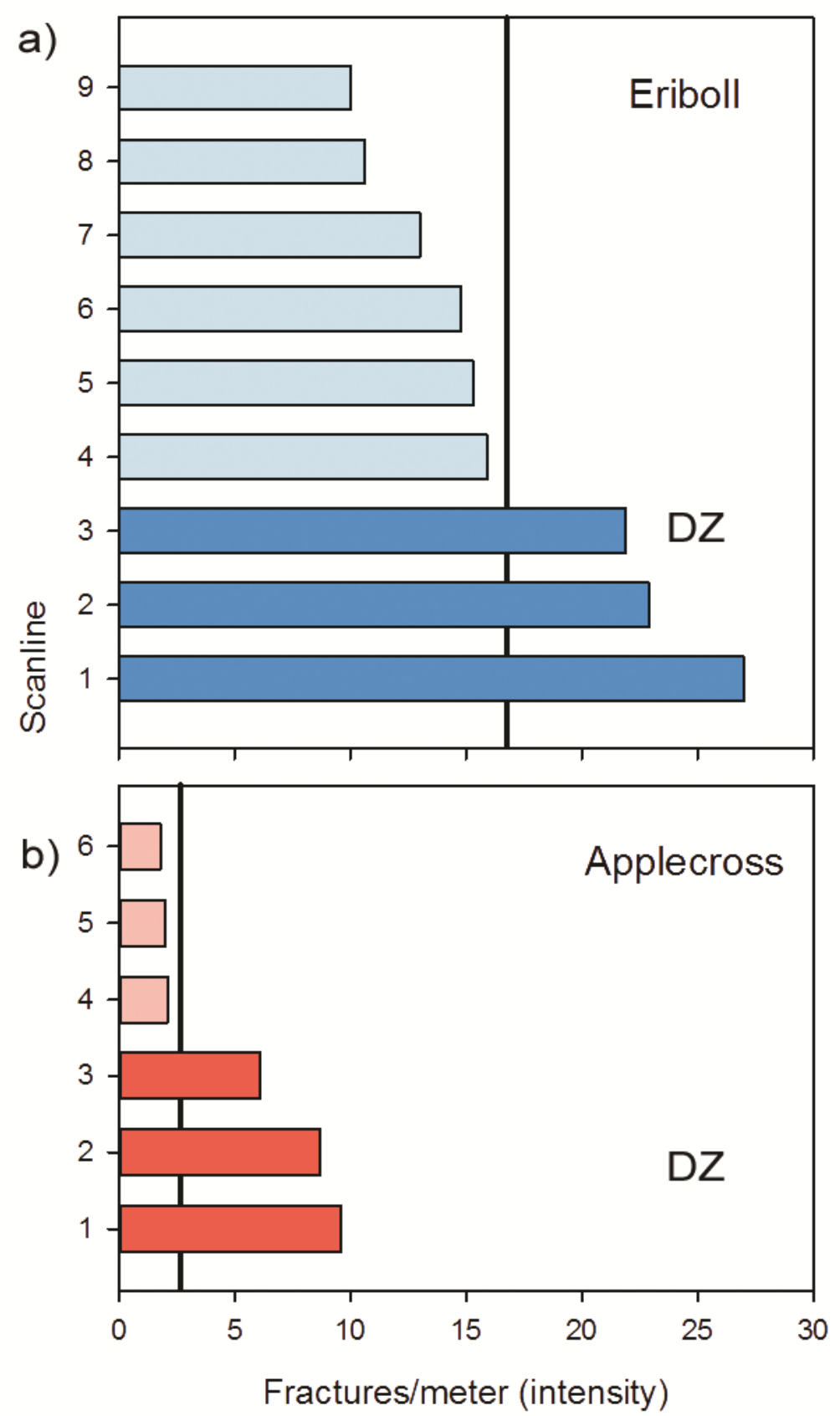


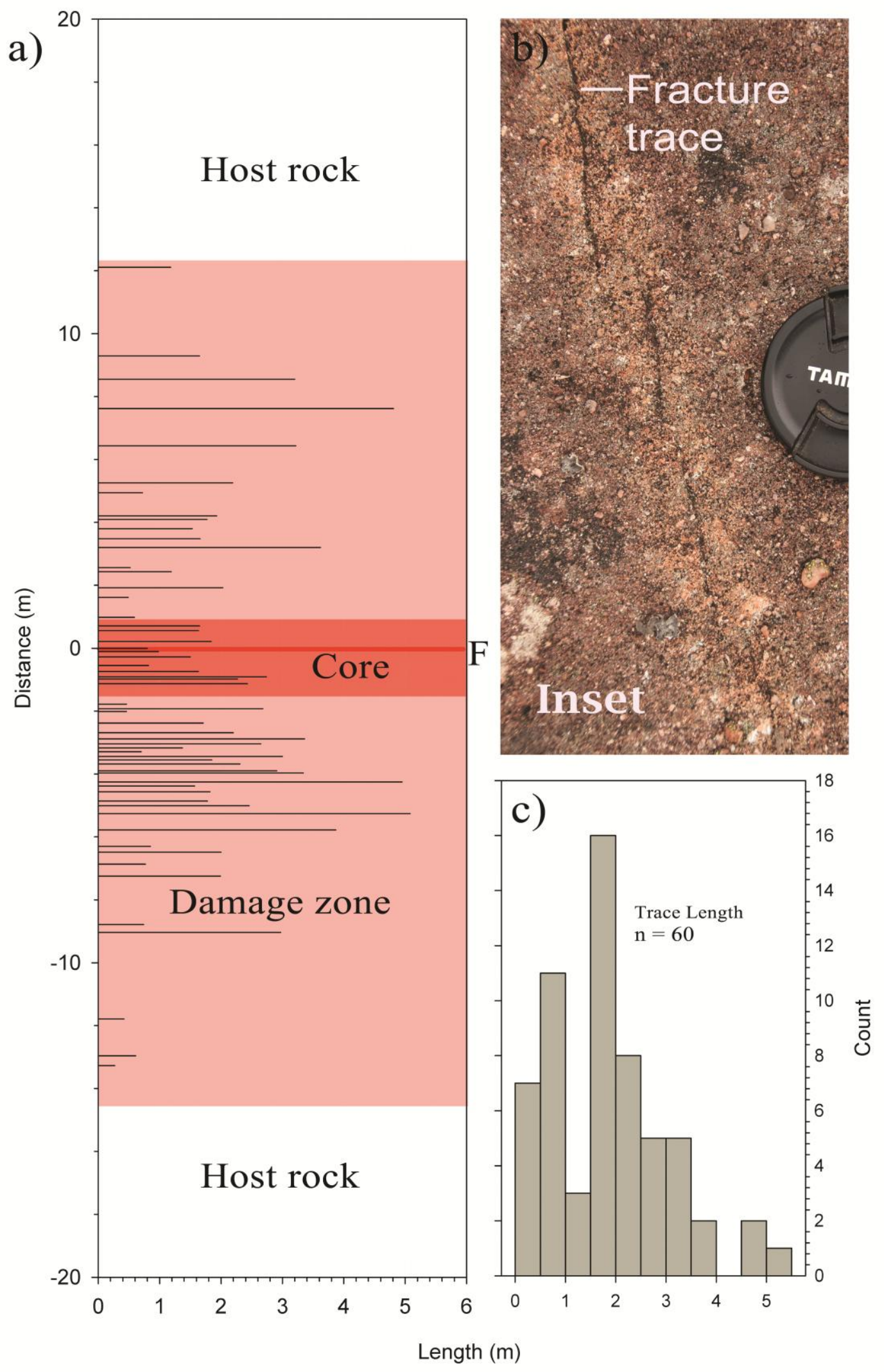




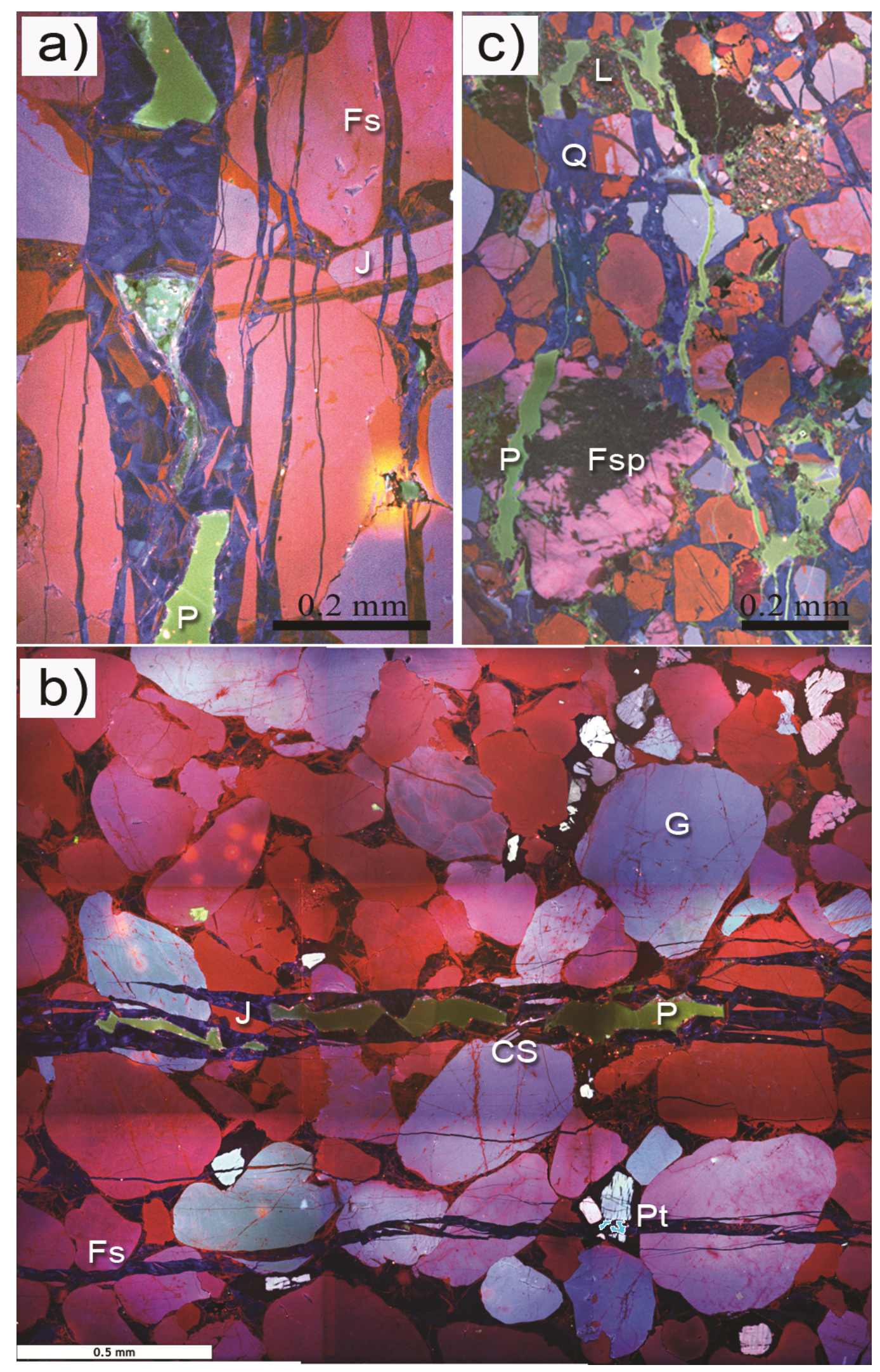



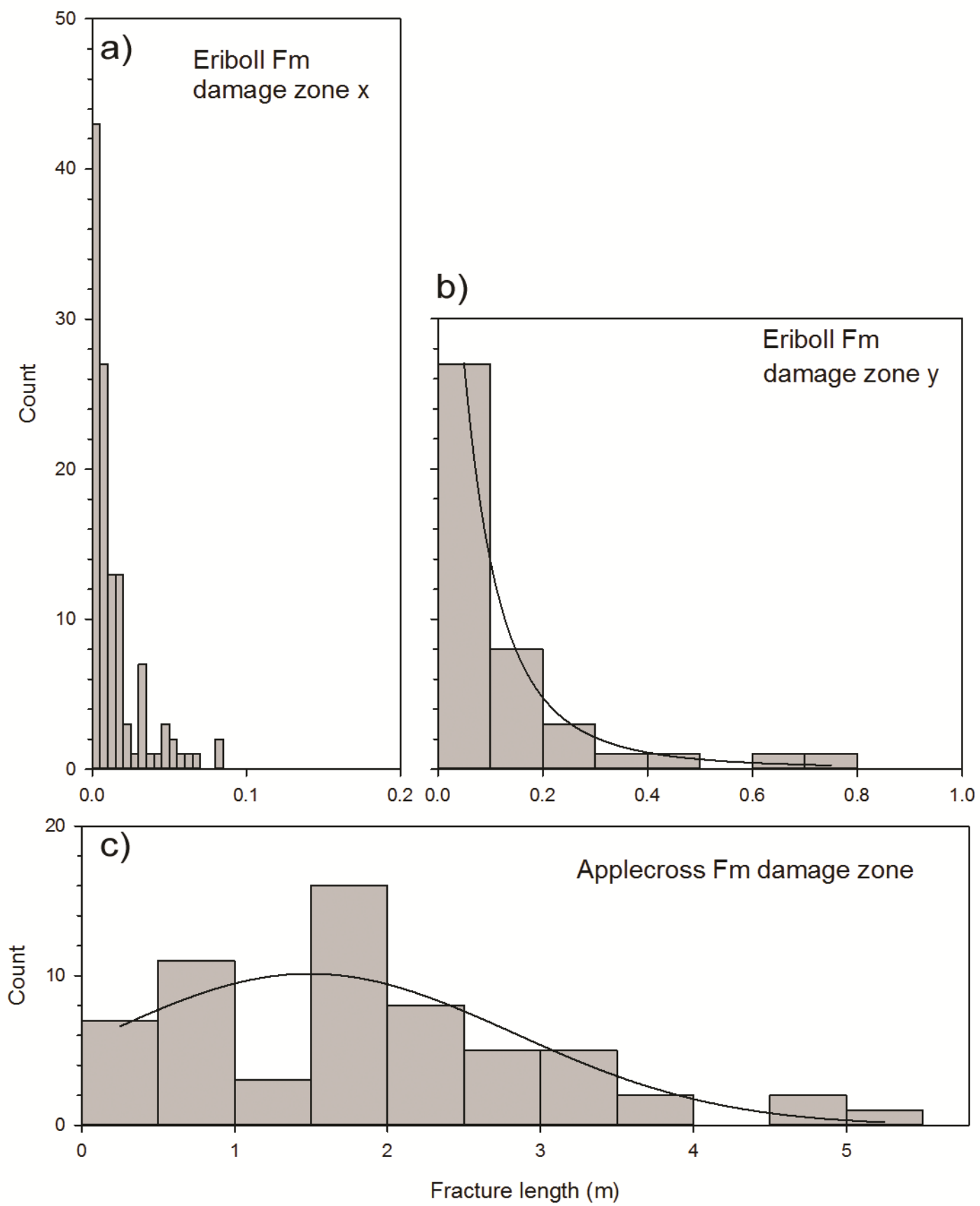


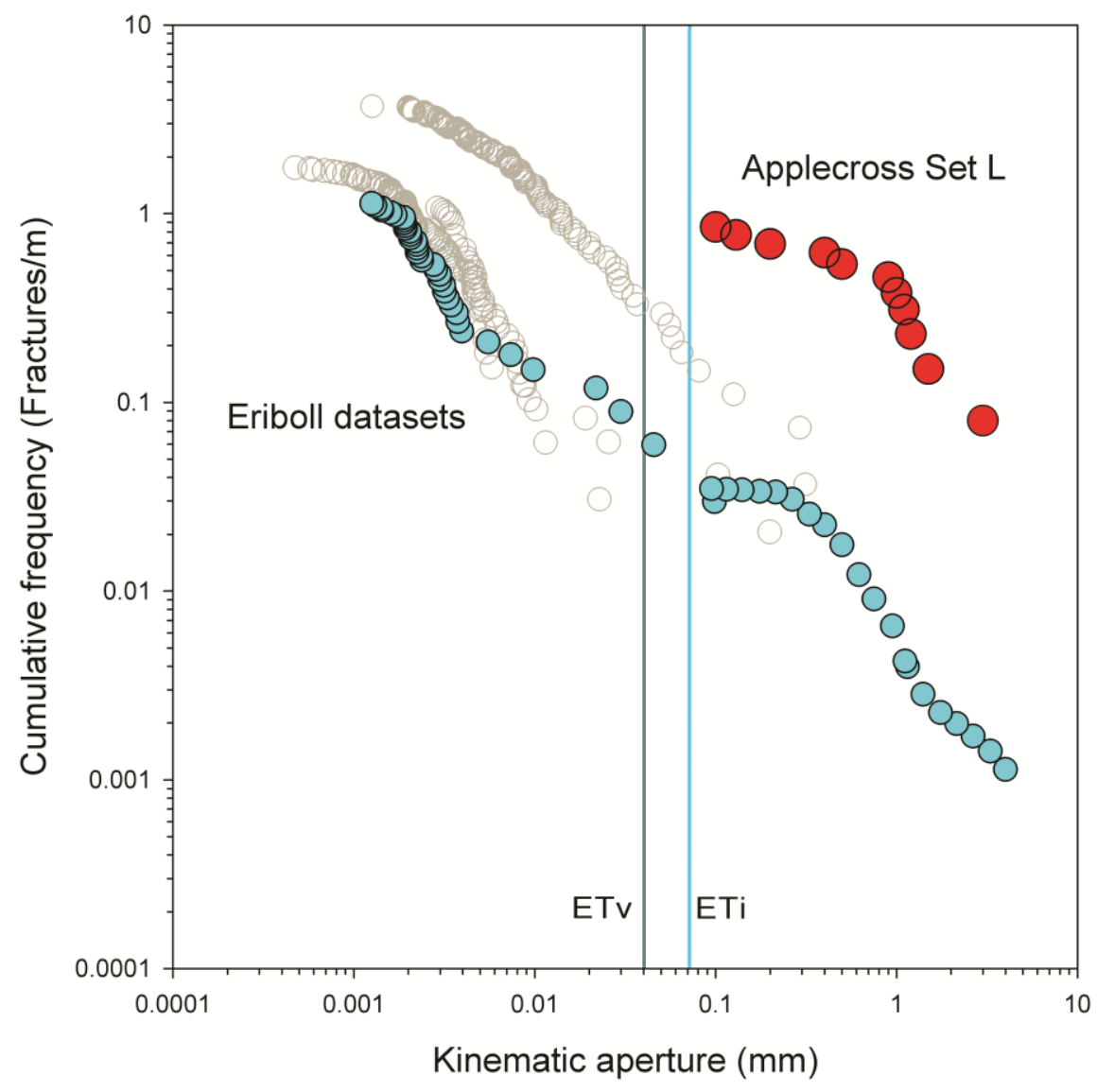


Table 1. Fault core and damage zone attributes of late faults.

\begin{tabular}{|c|c|c|c|c|c|c|c|c|}
\hline \multirow{3}{*}{$\begin{array}{l}\text { Host } \\
\text { Age/ } \\
n \\
n\end{array}$} & \multirow[t]{3}{*}{ Compositi } & Youn & \multicolumn{4}{|c|}{ Damage zone } & \multicolumn{2}{|c|}{ Core $^{1}$} \\
\hline & & & & & & & & \\
\hline & & $\begin{array}{l}\text { modulus } \\
\text { (avg. }\end{array}$ & $\begin{array}{l}\text { Fracture } \\
\text { attributes }\end{array}$ & $\begin{array}{l}\quad \text { Fracture } \\
\text { abundance } \\
\text { pattern }\end{array}$ & $\begin{array}{l}\text { Continu } \\
\text { ity; width }\end{array}$ & $\begin{array}{l}\text { Mode, } \\
\text { pattern }\end{array}$ & $\begin{array}{l}\text { Porosity/ } \\
\text { shape, width; } \\
\text { length }\end{array}$ & $\begin{array}{l}\text { Rock } \\
\text { types } \\
\text { (Inferred } \\
\text { role wrt flow) }\end{array}$ \\
\hline $\begin{array}{l}\text { Cambrian } \\
\text { Eriboll }\end{array}$ & $\begin{array}{l}\quad \text { Quartz } \\
\text { arenite } \\
\left(\mathrm{Q}_{95} \mathrm{~F}_{5} \mathrm{~L}_{0}\right) \\
\quad \sim 95 \% \text { prone to } \\
\text { quartz } \\
\text { accumulation }{ }^{2}\end{array}$ & $\mathrm{GPa}^{75}$ & $\begin{array}{l}\quad \text { Interconnec } \\
\text { ted, closely } \\
\text { spaced }(\mathrm{cm}) \text {, } \\
\text { short }(\mathrm{cm}-\mathrm{m}) \text {, } \\
\text { narrow }^{3}(\mathrm{~mm} \text { or } \\
\text { less), } \\
\text { interconnected, } \\
\text { mostly quartz } \\
\text { sealed }\end{array}$ & $\begin{array}{l}\quad \text { Abrupt } \\
\text { increase into } \\
\text { damage zone; } \\
\text { uniform } \\
\text { within; } \\
\quad \text { high } \\
\text { trace } \\
\text { connectivity }\end{array}$ & $\begin{array}{l}\quad \text { Continu } \\
\text { ous; Abrupt } \\
\text { margin; } m \\
\text { to tens of } m \\
\text { wide }\end{array}$ & $\begin{array}{l}\quad \text { Aligned } \\
\text { with fault \& } \\
\text { oblique slip; } \\
\text { wing crack } \\
\text { arrays }\end{array}$ & $\begin{array}{l}\quad \text { Porous/ } \\
\text { irregular to } \\
\text { tabular lenses; } \\
\text { variable width } \\
\text { \& length (10s } \\
\text { cm to m) }\end{array}$ & \begin{tabular}{l}
\multicolumn{1}{c}{ Quartz } \\
cemented \\
breccia with \\
vugs (conduit)
\end{tabular} \\
\hline $\begin{array}{l}\text { Neoproter } \\
\text { ozoic } \\
\text { Applecr } \\
\text { oss }\end{array}$ & $\begin{array}{l}\quad \text { Lithic } \\
\text { arkose to } \\
\text { feldspathic } \\
\text { litharenites } \\
\left(\mathrm{Q}_{60} \mathrm{~F}_{23} \mathrm{~L}_{17}\right) \\
\sim 60 \% \text { prone to } \\
\text { quartz } \\
\text { accumulation }{ }^{2}\end{array}$ & $\begin{array}{c}6.2 \\
\mathrm{GPa} \\
\text { Range: } \\
2.3-17 \mathrm{GPa}\end{array}$ & $\begin{array}{l}\quad \text { Isolated, } \\
\text { widely spaced } \\
(10 \mathrm{~s} \mathrm{~cm}) \text {, long } \\
(\mathrm{m}+) \text {, wide }(\mathrm{mm} \\
\left.\text { or more }{ }^{4}\right) \text {, } \\
\text { sporadically } \\
\text { quartz lined } \\
\text { mostly open }\end{array}$ & $\begin{array}{l}\quad \text { Gradual } \\
\text { increase } \\
\text { toward core; } \\
\text { low trace } \\
\text { connectivity }\end{array}$ & $\begin{array}{l}\quad \text { Continu } \\
\text { ous; Diffuse } \\
\text { margin, } m \\
\text { to tens of } m \\
\text { wide }\end{array}$ & $\begin{array}{l}\quad \text { Aligned } \\
\text { with fault \& } \\
\text { oblique slip; } \\
\text { wing crack } \\
\text { arrays }\end{array}$ & \begin{tabular}{l}
\multicolumn{1}{c}{ Non- } \\
porous; dense \\
/ tabular; \\
narrow $(10 \mathrm{~s}$ \\
$\mathrm{cm})$, long $(\mathrm{m}+)$
\end{tabular} & $\begin{array}{l}\quad \text { Indurated } \\
\text {, clay-rich } \\
\text { fault rock; } \\
\text { gouge } \\
\quad \text { (barrier) }\end{array}$ \\
\hline
\end{tabular}

